\title{
POLA MIGRASI, ENTREPRENEURSHIP DAN EKSPRESI KEAGAMAAN ORANG JAWA DI JAKARTA (Studi Kasus Masyarakat Lamongan)
}

\author{
Muhammad Ainun Nasikh \\ Mahasiswa Antropologi dan Sosiologi Agama \\ Sekolah Pascasarjana UIN Syarif Hidayatullah Jakarta
}

\begin{abstract}
ABSTRAK
Artikel ini menyimpulkan entrepreneuship orang Lamongan di Jakarta terkonstruksi dalam sebuah dialektika bukan karena faktor lingkungan sosial budaya yang bersifat ekslusi sosial. Melainkan motivasi dalam konfigurasi mobilitas sosial climbingsebagai opsi mentransformasi status sosial (achieved status) di masyarakat secara vertikal. Konklusi ini sesuai dengan deskripsi informan yang berwirausaha dalam sektor kuliner. Temuan ini menunjukan lingkungan sosial budaya hanya memberi implikasi terhadap tipologi kesadaran diskursif pada pola migrasi masyarakat Lamongan ke Jakarta.

Perilaku kewirausahaan orang Lamongan di Jakarta ditentukan oleh motivasi berprestasi (need of achievement) yang memberikan stimulus terhadapperkembangan masyarakat.Adanya interaksi masyarakat Jawa dengan pasar disertai dengan intensitas kepemilikan lahan. Memberikan implikasi pada aktivitas ekonomi berskala makro yang menyebabkan heterogenitas profesi masyarakat Jawa. Lebih lanjut, kebudayaan Jawa tidak kontras dengan sistem perdagangan dan kewirausahaan.

Sementara itu, penulis tidak sependapat dengan konklusi yang mengidentifikasi pandangan mengenai korelasi antara nilai-nilai budaya dan perilaku kewirausahaan. Penjelasan mengenai konstruksi entrepreneurship didasarkan atas asumsi masyarakat yang menanamkan nilai-nilai kewirausahaan akan banyak orang yang menjadi wirausaha. Seperti adanya warisan culture priayiyang menyebabkan masyarakat Jawa berorientasi sebagai Pegawai Negeri Sipil (PNS) di kota-kota administratif.
\end{abstract}

Kata Kunci : Migrasi, entrepreneurship, mobilitas sosial, budaya.

\section{A. Pendahuluan}

Perkembangan ekonomi yang disebabkan kompetisi usaha telah membawa implikasi terhadap kehidupan masyarakat. ${ }^{1}$ Pembangunan ekonomi

${ }^{1}$ Pasar bebas sering dianggap tidak siap untuk mengatasi masalah sosial seperti bahaya lingkungan, ketimpangan, masalah kesehatan, pengangguran, kejahatan, dan sebagainya). Karena pasar dianggap tidak memiliki kapasitas untuk 
suatu negara menyebabkan terjadinya transformasi budaya. ${ }^{2}$ Problem kultural adalah hambatan intern yang berasal dari masyarakat karena rendahnya etos kerja. Eksistensi kebutuhan tersier yang diciptakan manusia memberikan implikasiterhadap aspek transformasi sistem mata pencaharian. Mayoritas masyarakat pedesaan secara general bermata pencaharian sebagai petani (peasant communities) dan nelayan (fishing communities). ${ }^{3}$ Kondisi geografis dimana entitas masyarakat berdomisili dapat mengkonstruk sistem mata pencaharian. Masyarakat yang tinggal di area pesisiran secara general bermata pencaharian sebagai nelayan. Asumsi ini didasarkan pada ketersediaan sumber daya alam yang berasal dari laut. Berbeda dengan masyarakat yang tinggal di daerah pegunungan yang mayoritas bermata pencaharian sebagai petani.

Masyarakat Indonesia pada dasarnya mempunyai kesempatan yang sama untuk bermobilitas sosial, terutama dalam aspek ekonomi. Keterbatasan lahan pertanian serta motivasi untuk meningkatkan status sosial dapat menjadi stimulus terhadap transformasi sistem mata pencaharian suatu masyarakat. Manusia sebagai mahluk utilitarian mempunyai kecenderungan berpikir secara rasional ketika mengadopsi resiko. Kalkulasi income sebagai media transformasi status sosial menjadi pertimbangan yang intens bagi masyarakat gemeinchaft dalam mengambil opsi dalam bekerja.Masyarakat Jawa secara umum menempatkan status sosial bukan hanya berdasarkan indikator kekayaan atau akumulasi materi.

Status sosial pada aspek pemerintahan adalah diantara indikator yang memberikan konfigurasi orientasi kerja masyarakat Jawa. Berbeda dengan masyarakat Cina yang menempatkan status sosial berdasarkan akumulasi kekayaan. Pola kehidupan sosial dalam bentuk stratifikasi sosial masyarakatnya di tentukan oleh kinerja mereka dalam menghimpun kekayaan. Pola kehidupan masyarakat Jawa mengkonstruksi suatu tatanan sosial yang menyebabkan sebagian besar masyarakatnya berorientasi pola

memecahkan masalah sosial, tanggung jawab ini biasanya diserahkan kepada sektor publik. Lihat, Alex Nicholls, eds. Social Entrepreneurship: New Models of Sustainable Social Change, (New York: Oxford University Press, 2006), 72.

${ }^{2}$ Tanguy Bernard, Alain De Janvry, Elisabeth Sadoulet, "When Does Community Conservatism Constrain Village Organizations?," The University of Chicago Press, Source: Economic Development and Cultural Change, Vol. 58, No. 4 (July 2010), 609-641.

3 Koentjaraningrat, Pengantar Ilmu Antropologi Edisi Revisi (Jakarta: PT Rineka Cipta, 2009), 217. Orang desa biasanya bekerja sebagai petani karena mentalias mereka adalah petani. Sementara orang perkotaan biasanya bekerja sebagai buruh, pedagang dan pegawai serta berwirausaha. Mereka mempunyai motivasi yang lemah untuk menjadi wirausahawan. Lihat juga, Koentjaraningrat, Kebudayaan Mentalitas dan Pembangnan (Jakarta: PT Gramedia, 2008), 37. 
kerja di pemerintahan yang dikenal dengan budaya priayi atau ambtenaar. Sistem priayi di Jawa menurut Denys Lombard (1990), tidak selamanya diwariskan oleh orang tua kepada anak-anak mereka. Culturepriayi berkembang dari abad ke-17 dan diwariskan sampai saat ini. ${ }^{4}$

Namun bahan-bahan etnografis menunjukan bahwa culture Jawa tidak menolak perdagangan. Keakraban masyarakat Jawa dengan pasar tidak mengherankan ketika pedagang-pedagang yang berasal dari Jawa dengan mudah dapat membedakan transaksi yang bersifat sosial dan ekonomi. Orang Jawa terlibat perdagangan namun tidak dalam akumulasi kekayaan, mereka adalah pengusaha yang bukan kapitalis. ${ }^{5}$ Perubahan sosial suatu masyarakat yang menilai status sosial bukan di dasarkan pada aspek pendidikan atau jabatan dapat membentuk pola kehidupan yang baru. Orientasi masyarakat yang pada awalnya bekerja sebagai Pegawai Negeri Sipil (PNS) atau pemerintahan secara gradual dapat tereduksi. Prestasi pada aspek akademisi akan mengalami degradasi ketika masyarakat menghadapkan pencapaian pengetahuan dan status sosial dalam dunia kerja tidak lagi menjadi sebuah indikator yang intens.

Reifikasi sosial yang menjadi sebuah indikator ketika menilai status sosial individu ditengah-tengah masyarakat ditentukan oleh eksistensi materi. Fenomena pola kehidupan materialisme dapat merubah sistem berpikir (mindset) masyarakat yang terdiri dari entitas-entitas individu. Aspek prestasi dalam bidang akademisi dan status kepangkatan dalam dunia kerja tidak lagi menjadi sebuah nilai yang vital. Pemaknaan status sosial terhadap individu pada fase yang demikian ditentukan oleh akumulasi materi.

Alih profesi dianggap sebagai sebuah opsi yang tepat sebagai mekanisme dalam meningkatkan income guna memenuhi kebutuhan hidup. Masyarakat pedesaan tidak lagi memandang bahwa bekerja sebagai petani ataupun nelayan dapat menambah kekayaan mereka secara massif. Ketiadaan lahan pertanian menjadi faktor yang dapat merubah pola sistem mata pencaharian masyarakat. Aktivitas individu yang tidak mempunyai lahan pertanian pada umumnya bergantung pada sektor yang lain. Untuk memenuhi kebutuhan hidup, mereka pada umumnya bekerja sebagai buruh tani dan serabutan.

Kewirausahaan merupakan diantara opsi yang memberikan ekspektasi besar dalam akumulasi kekayaan. Profesi yang demikian banyak memberikan

${ }^{4}$ Denys Lombard, Le Carrefour Javanais (Paris: Ecole des Hautes Etudes en Sciences Sociales, 1990), 103. Diterjemahkan oleh, Winarsih Partaningrat Arifin dkk, Nusa Jawa: Silang Budaya Kajian Sejarah Terpadu (Jakarta: Gramedia Pustaka Utama), 103.

5 Robert W. Hefner, Eds. Budaya Pasar: Masyarakat dan Moralitas dalam Kapitalisme Asia Baru (Jakarta: PT. Pustakan LP3ES, 2000), 303-304. 
ketidakpastian dalam upaya menghimpun kekayaan. Mayoritas masyarakat Indonesia umumnya masih enggan untuk memilih profesi sebagai seorang wirausaha. Diantara faktor yang menghambat terbentuknya perilaku entrepreneur adalah dikarenakan sikap individu yang tidak ingin berkompetisi. ${ }^{6}$ Termasuk konsep etos kerja nerima ing pandum (menerima segala pemberian apa adanya). ${ }^{7}$

Pada kasus tertentu, jenis pekerjaan yang demikian dianggap menjanjikan serta tidak membutuhkan sebuah legalitas pendidikan dalam kontinuitasnya. Keberhasilan dalam berwirausaha memang menjadi harapan semua orang. Meskipun tidak semuanya menuai keberhasilan sebagaimana yang diharapkan. ${ }^{8}$ Golongan masyarakat yang tidak mempunyai pendidikan yang layak secara umum mengambil opsi bekerja pada sektor non formal yang tidak membutuhkan gelar secara akademisi. Pertimbangan yang penting pada sektor entrepreneur bukan ditentukan oleh hanya reproduksi dunia pendidikan semata. Masyarakat yang tidak mempunyai pendidikan yang layak senantiasa termotivasi untuk berwirausaha ketika ingin memperbaiki kehidupan ekonominya. Diantara mereka bahkan banyak yang eksis ketika menjalankan usaha di berbagai sektor di kota-kota besar di Indonesia.

Masyarakat migran dari golongan bawah mayoritas belajar kewirausahaan dari pendidikan kewirausahaan pada tempat mereka magang atau bekerja. Pola edukasi yang demikian secara aktif banyak memproduksi wirausahawan kelas kaki lima yang bergerak dalam berbagai sektor perekonomian. Termasuk dalam sektor kuliner yang dianggap tidak membutuhkan banyak skill dan modal yang besar untuk menjalankan usaha. Eksistensi usaha kecil di kota-kota besar diharapakan memberikan kontribusi dalam mereduksi pengangguran.Masyarakat Lamongan merupakan diantara sekian banyak kelompok masyarakat migran yang terdapat di Jakarta. Secara umum, jenis usaha kuliner menjadi orientasi masyarakat Lamongan. Opsi sektor kuliner merupakan jenis usaha yang menjadi pertimbangan penting bagi orang Lamongan yang bermigrasi ke-Jakarta. Sektor kewirausahaan yang dijalankan oleh orang Lamongan telah memberikan impact yang intens dalam mereduksi kuantitas pengangguran di kota-kota besar di Indonesia seperti Jakarta.

${ }^{6}$ Willy Arafah,Esensi Lingkungan Bisnis dan Entrepreneurship (Jakarta: Univaersitas Trisakti, 2010), 27.

7 Suwardi Endraswara, Etnologi Jawa: Penelitian, Perbandingan, dan Pemaknaan Budaya (Yogyakarta: Center for Academic Publishing Service, 2015), 136.

${ }^{8}$ Kasmir, Kewirausahaan (Jakarta: PT Raja Grafindo Persada, 2006), 30. 
Berbeda dengan masyarakat Jawa pada umumnya yang berorientasi sebagai priayiataupegawai negeri. ${ }^{9}$ Profesi seorangpriayi dapat membawa seseorang untuk bergaul dengan bebagai lapisan masyarakat. Pandangan hidup diukur berdasarkan banyaknya teman dalam sistem kehidupan masyarakat Jawa (blater) yang menjadi sebuah filosofi. ${ }^{10}$ Masyarakat Lamongan mempunyai perbedaan dengan masyarakat Jawa pada orientasi kerja sebagai wirausaha. Dalam bahasa Jawa ada sebuah akronim untuk mendeskripsikan motivasi masyarakat Lamongan dalam mengembangkan semangat kewirausahaannya yakni: bondonekat atau bonek sebagai ungkapan yang mempunyai arti modal nekat dalam mengawali segala sesuatu. Termasuk dalam memulai menjalankan usaha di Jakarta.

Fenomena kewirausahaan masyarakat Lamongan menjadi sebuah kajian yang unik. Ditengah berbagai program pemerintah atau swasta untuk mendirikan institusi yang memberikan edukasi dan skillberwirausaha. Kewirausahaan masyarakat Lamongan mempunyai peran penting sebagai problemsolving pengangguran. Metode pembelajaran yang diterapkan kewirausahaan masyarakat pedesaan khususnya warga Lamongan adalah learning by working, yakni bekerja sambil belajar.

Latar belakang culture merupakan diantara faktor yang menyebabkan dan membentuk perilaku masyarakat. Budaya masyarakat yang menilai perilaku atau status sosial bukan ditentukan oleh faktor kekayaan dapat mengkonstruksi suatu tatanan sosial yang berorientasi pada pemenuhan kebutuhan sehari-hari. Masyarakat yang demikian ini biasanya bersifat sederhana dan membentuk suatu tatanan kehidupan sosial yang teratur. Para pemuda atau penduduk dapat merasa nyaman ketika menempati kampung halamannya. Sistem kehidupan yang dibangun bukan didasarkan pada akumulasi kekayaan semata. Melainkan dari aspek menjalankan nilai dan tatanan sosial secara holistic.

Setiap masyarakat pada dasarnya mempunyai peranan(role) yang sama dalam memperbaiki sistem mata pencahariannya. Mereka mampu menjadi petani dan pedagang sesuai dengan potensi. Faktor geografis hanyalah sebagian kecil diantara beberapa sebab yang mempengaruhi. Budaya ambtenaar yang diwariskan oleh Belanda sampai saat ini masih dijalankan oleh masyarakat Indonesia. Sebagian besar mereka mempunyai motivasi bekerja sebagai pegawai pemerintahan atau yang dikenal dengan budaya priayi.

${ }^{9}$ Niels Murder, Petualangan Seorang Antropolog di Jawa (Yogyakarta: Kanisius, 2007), 156.

10 Sartono Kartodirjo, A. Sudewo dan Suhardjo Hatmosuprobo, Perkembangan Peradaban Priayi (Yogyakarta: Gadjah Mada University Press, 1993), 158-157.

286 | INDO-ISLAMIKA, Volume 5 No. 2 Juli - Desember 2015/1438 
Situasi ekonomi yang kurang baik disertai dengan minimnya kemampuan mengembangkan karir pada akhirnyamenyebabkan masyarakat desa bermigrasi ke-kota. Krisis ekonomi ketika dihadapkan pada transformasi sosial masyarakat tidak lagi menjadi hambatan dalam mengingkatkan kemapanan kehidupan. Kebutuhan individu yang meningkat pada akhirnya membawa implikasi berupa perubahan sosial (social change), yakni fase dimana masyarakat semakin individualis dan mementingkan aspek materi.

Kondisi lokal masyarakat yang tidak nyaman serta kehidupan perkotaan yang dianggap memberikan peluang yang menjanjikan menjadikan push and pull antara pedesaan dengan perkotaan. Masyarakat desa mempunyai asumsi bahwa kehidupan yang mereka jalankan di daerah asal tidak memberikan prospek yang baik. Kontrol sosial yang kuat disertai peluang yang minim mengakibatkan masyarakat desa bemigrasi ke kota-kota besar. Dengan adanya kontrol yang kuat menyebabkan ruang gerak masyarakat desa terasa sempit dan tidak leluasa dalam mengembangkan karirnya sebagaimana di kota-kota besar.

Dalam kehidupan, manusia mempunyai kebutuhan yang bersifat materiil dan non materiil atau jasmani dan rohani. Kebutuhan materiil erat kaitannya dengan pemenuhan kebutuhan yang bersifat jasmaniah sebagai sarana melanjutan kelangsungan hidup. Makan dan minum serta berbagai sarana kebutuhan lain diperjuangakan manusia guna meneruskan kehidupan. Sementara kebutuhan yang bersifat rohani atau batiniah erat kaitannya dalam upaya untuk meningkatkan status sosialnya. Kebutuhan ini lebih bersifat pada upaya pemuasan nilai dan nama dalam kehidupan masyarakat. Kelompok individu menetapkan berbagai indikator khusus yang menjadi tolok ukur tinggi rendahnya status sosial seseorang.

Perubahan sosial dalam masyarakat desa erat kaitannya dengan sistem mata pencaharian yang berhubungan dengan kondisi alam. Termasuk beralihnya mata pencaharian yang awalnya dari petani pada sektor yang lain. Masyarakat yang mempunyai lahan yang minim mensiasati penambahan kebutuhannya dengan profesi sampingan. Berdagang merupakan pekerjaan yang erat kaitannya dengan kalangan ibu-ibu. Sedangkan bertani identik dengan pekerjaan yang dilakukan oleh kalangan laki-laki. ${ }^{11}$

Adanya perubahan kondisi musim menyebabkan petani mengalami ketergantungan yang tinggi dengan alam. Mereka hanya mengandalkan mata pencahariannya dalam sektor pertanian semata tanpa tergantung dengan mencari sumber pendapatan yang lain. Para antropolog mengkaji tentang cara hidup manusia dengan mengumpulkan data mengenai proses ekonomi

\footnotetext{
${ }^{11}$ Bambang Pranowo, Memahami Islam Jawa (Jakarta: Pustaka Alvabet, 2009), 95.
}

INDO-ISLAMIKA, Volume 5 No. 2 Juli - Desember 2015/1438 | 287 
atas budaya lokal. ${ }^{12}$ Termasuk aktivitas sistem mata pencaharian yang tergantung dengan kondisi alam.

Budaya masyarakat desa yang masih berorientasi pada pegawai dengan gaji bulanan yang stabil serta rendahnya kualitas etos kerja. Mengakibatkan meningkatnya jumlah pengangguran yang dapat menimbulkan problem sosial seperti kemiskinan, kriminalitas dan masalah-masalah sosial lainnya. ${ }^{13}$ Pengangguran merupakan problem sosial yang merugikan serta menimbulkan berbagai dampak negatif.Ketidaksesuaian antara skill dengan dunia kerja dapat menyebabkan kinerja kerja yang kurang efektif. Sebuah kondisi dihadapkan dengan pekerjaan yang tidak sesuai dengan keahlian yang tidak berkorelasi. Sebuah koreksi bagi kalangan sarjana ataupun catatan penting bagi para pemerintah. Sebab sarjana mempunyai modal penting berupa Sumber Daya Manusia (SDM) yang berkualitas. ${ }^{14}$

Orientasi masyarakat untuk menjadi pegawai dengan gaji bulanan yang stabil menjadi faktor utama terjadinya fenomena sosial yang demikian. ${ }^{15}$ Mindset masyarakat yang merasa lebih bergengsi bilamana bekerja pada sebuah perusahaan besar ataupun instansi pemerintahan daripada membuka lapangan kerja baru dari awal. Adanya warisan budaya yang lebih berorientasi pada keinginan untuk menjadi pegawai lebih tinggi daripada keinginan untuk menciptakan lapangan pekerjaan. Sebagaimana yang terjadi pada masyarakat pedesaan yang berorientasi pada pekerjaan yang menjamin kemapanan hidup daripada berhadapan dengan resiko yang tidak pasti. Mayoritas masyarakat desa menjual tanah dan ternaknya agar anak-anak mereka diterima bekerja dalam instansi pemerintahan dan perusahaan-perusahaan swasta.

Faktor budaya berperan secara efektif memajukan orientasi kewirausahaan suatu masyarakat. Terutama budaya nasional yang ditandai dengan individualisme yang kuat. Sedangkan budaya yang bersifat hierarkis 2012), 46.

12 Beni Ahmad Sebani, Pengantar Antropologi (Bandung: Pustaka Setia,

13 Alex Nicholls, eds. Social Entrepreneurship: New Models of Sustainable Social Change, (New York: Oxford University Press, 2006), 322.

14 Hans Westlund and Roger Bolton, "Local Social Capital and Entrepreneurship," Small Business Economics, Special Issue on Entrepreneurship, Firm Growth and Regional Development in the New Economic Geography. Vol. 21, No. 2, (Sep, 2003), 77-113.

${ }^{15}$ Hongbin Li, Lei Li, Binzhen Wu and Yanyan Xiong, "The End of Cheap Chinese Labor," The Journal of Economic Perspectives, Vol. 26, No. 4 (Fall 2012), 57-74. 
umumnya meenjadi penghalang orientasi kewirausahaan. ${ }^{16} \mathrm{Mc}$ Clelland (1961), menekankan kewirausahaan ditentukan karena kebutuhan prestasi (need of achievement). Termasuk indikator di dalamnya adalah motivasi untuk meningkatkan status sosial.

Koentjaraningrat (2007), mendefinisikan adanya warisan budaya priayi menyebabkan sebagian besar masyarakat Jawa memilih bekerja sebagai pegawai pemerintahan atau Pegawai Negeri Sipil (PNS) serta pegawai perkantoran. ${ }^{17}$ Mayoritas jabatan dalam struktur suatu instansi pemerintahan baik pusat maupun daerah banyak didominasi oleh orang-orang Jawa. Penulis dalam hal ini menemukan seorang yang merantau ke Singkawang Kalimantan Barat karena merasa lebih termotivasi bekerja dalam sektor pemerintahan daripada berwirausaha. ${ }^{18}$ Kondisi yang demikian banyak terjadi pada masyarakat Jawa Tengah dan Timur. ${ }^{19}$

Masyarakat Jawa yang terfragmentasi antara golongan priayi yang terkonfigurasi dari pegawai negeri dan kaum terpelajar dengan golongan yang disebut wong cilik yang terdiri dari petani, tukang-tukang dan pegawai kasar lainnya. Suatu kelemahan pembangunan masyarakat pedesaan di Jawa adalah sikapnya yang pasif terhadap hidup. Kesukaan mereka terhadap kebatinan, penilaian tinggi terhadap sikap nerima ing pandum, dan tetap tabah dalam hal penderitaan menjadi penghambat kemajuan mereka. ${ }^{20}$ Masyarakat di Indonesia khususnya masyarakat Jawa yang tinggal disebuah pedesaan hampir mayoritas bekerja dalam peasant communities dengan berorientasi menjadi pegawai negeri (kebudayaan priayi) di kota-kota administratif. $^{21}$

Masyarakat Indonesia, khususnya masyarakat Jawa yang tinggal di daerah pesisiran mayoritas bekerja sebagai nelayan yang masuk dalam kategori fishing communities. Tidak bisa dikesampingkan bahwa kondisi geografis turut berperan serta dalam membentuk adanya diferensiasi budaya. Kebudayaan yang ada dalam masyarakat pedesaan tentu mempunyai

16 Marta Peris-Ortiz, José M. Merigó-Lindahl, Eds. Entrepreneurship, Regional Development and Culture An Institutional Perspective, (Switzerland: Springer International Publishing, 2015), 25.

17 Koentjaraningrat, Manusia dan Kebudayaan di Indonesia (Jakarta: Djambatan, 2007), 392.

18 Wawancara dengan seorang pegawai pemerintahan di Singakawang Kalimantan Barat pada Pertengahan April 2013.

${ }^{19}$ Koentjaraningrat, Kebudayaan Mentalitas dan Pembangnan (Jakarta: PT Gramedia, 2008), 37.

20 Koentjaraningrat, Manusia dan Kebudayaan di Indonesia (Jakarta: Djambatan, 2007), 350.

${ }^{21}$ Koentjaraningrat, Pengantar Ilmu Antropologi Edisi Revisi (Jakarta: PT Rineka Cipta, 2009), 220. 
diferensiasi dengan kebudayaan yang ada dalam masyarakat perkotaan. Sebagai alat analisis yang memanfaatkan kerangka integratif usaha kecil. Perhatian diberikan pada sosial, budaya yang menjadi aspek yang mempengaruhi dan dipengaruhi oleh bagaimana seorang wirausaha beroperasi dalam lingkungan ekonomi mereka. ${ }^{22}$

Bentuk konkrit dari wirausaha adalah kemampuan yang dimiliki oleh seseorang untuk melihat dan menilai kesempatan-kesempatan membuka usaha. Kelaziman dan keunikan dari membuka usaha merupakan sikap dalam menganalisis peluang kemungkinan menjalankan usaha. ${ }^{23}$ Menghimpun sumber daya yang dibutuhkan untuk mengambil tindakan yang tepat guna memperoleh profit. Kewirausahaan disebut sebagai sebuahperilaku seseorang yang didasarkan untuk melihat peluang guna merealisasikan ideidenya. ${ }^{24}$ Seorang entrepreneursecara insting mampu melihat dan menciptakan peluang (opportunity) kerja yang kemudian di implementasikan menjadi sesuatu yang lebih bernilai secara materiil dan sosial.

Banyaknya anggota masyarakat yang membuka lapangan pekerjaan diharapkan mampu untuk meminimalisir pengangguran. Krisis moneter yang terjadi pada tahun 1997 telah menyebabkan banyak pengangguran dimanamana. ${ }^{25}$ Pasca reformasi, kecenderungan antara produksi dan kebutuhan tidak ada. ${ }^{26}$ Suatu negara dikatakan sejahtera bilamana sebagian besar masyarakatnya membuka usaha guna meningkatkan produktivitas.Perubahan sosial ditentukan oleh faktor internal dan eksternal. Faktor internal lebih disebabkan karena adanya kalangan individu yang menghendaki adanya perubahan tersebut. Sedangkan faktor eksternal merupakan faktor yang berasal dari luar masyarakat. William Oughburn berpendapat bahwa perubahan sosial disebabkan karena kondisi primer seperti georgafis ekonomis dan sebagainya. $^{27}$

${ }^{22}$ Sarah Turner, Indonesia's Small Entrepreneurs Trading on the Margins (London: Routledge Curzon, 2003), 10.

${ }^{23}$ Patrick J. Murphy and Susan M. Coombes, "A Model of Social Entrepreneurial Discovery," Journal of Business Ethics, Vol. 87, No. 3 (Jul., 2009), 325-336.

${ }^{24}$ Sukamdani Sahid Gitosarjono, Bisnis dan Kewirausahaan Syariah: Upaya Menuju Kesejahteraan Umat Islam (Bogor: Sekolah Tinggi Agama Islam Terpadu Modern Sahid, 2012), 26.

${ }^{25}$ Zainuddin Maliki, Agama Priyayi: Makna Agama di Tangan Elit Penguasa (Yogyakarta: Pustaka Marwa, 2004), 132.

${ }^{26}$ Jacobus Ranjabar, Perubahan Sosial Dalam Teori Makro: Pendekatan Realitas Sosial (Bandung: Alfabeta, 2005), 121.

27 Soerjono Soekanto, Sosiologi Suatu Pengantar (Jakarta: Raja Grafindo Persada, 2002), 306. 
Kelompok entrepreneur merupakan agent of change dalam suatu masyarakat. Sebagai ilustrasi adalah para entrepreneur memainkan peranan penting filantropi sosial. Bagi negara-negara berkembang, kelompok entrepreneur memiliki kontribusi dalam mengelola sumber daya alam maupun sumber daya manusia. ${ }^{28}$ Fenomena sosial yang demikian menyebabkan pemerintah melakukan kebijakan khusus dalam institusi pendidikan. Lembaga pendidikan kemudian dibentuk tidak hanya berorientasi pada penciptaan lulusan yang hanya mencari kerja semata. Namun lebih ditekankan agar mampu untuk menciptakan pekerjaan baru dengan menganalisis peluang yang ada. ${ }^{29}$

Kewirausahaan dalam skala mikro diharapkan mampu memenuhi kebutuhan masyarakat sesuai dengandaya beli. ${ }^{30}$ Home industri yang hanya memproduksi barang dalam skala kecil setidaknya dapat menampung tiga sampai enam karyawan sekitar. Barang yang mereka hasilkan lebih berkualitas daripada produk yang dihasilkan oleh pabrik yang berskala besar. ${ }^{31}$ Eksistensi home industri diharapkan mempunyai andil guna menjaga nilai kearifan lokal dengan tetap mempekerjakan kalangan masyarakat sekitar atau anggota keluarga. Nilai gotong-royong menjadi sebuah hal yang umum bagi masyarakat ketika anggotanya terjun dalam bidang home industri.

Masyarakat yang membuka usaha tidak terlepas dari perilaku yang mendesain mereka. Kasus ini memberikan gambaran umum bahwa seorang entrepreneur tidak hanya dibentuk oleh institusi pendidikan yang berorientasi pada penciptaan lapangan kerja. Melainkan kemampuan sikap internal berkomunikasi dalam bentuk kerja sama tim secara interdisipliner. ${ }^{32}$ Paul Tracey and Nelson Phillips (2007), menyatakan peran pendidikan wirausaha memberikan kontribusi penting mengembangkan pola berpikir. Lebih lanjut

28 David Schultz, "Blue-Collar Teaching in a White-Collar University," Journal of Public Affairs Education, Vol. 18, No. 1 (WINTER 2012), 67-86.

29 Thomas A. Bryer and Daniel Seigler, "Theoretical and Instrumental Rationales of Student Empowerment Through Social and Web-Based Technologies," Journal of Public Affairs Education National Association of Schools of Public Affairs and Administration, Vol. 18, No. 3 (SUMMER 2012), 429-448.

${ }^{30}$ Briana Cummings, "Benefit Corporations: How to Enforce a Mandate to Promote the Public Interest," Columbia Law Review, Vol. 112, No. 3 (APRIL 2012), 578-627.

${ }^{31}$ Wawancara dengan Seorang Perajin sandal dari Lamongan Sandal di daerah Waru Sidoarjo Pertengahan 2014.

${ }^{32}$ Eli Jones, James A. Roberts and Lawrence B. Chonko, "Motivating Sales Entrepreneurs to Change: A Conceptual Framework of Factors Leading to Successful Change Management Initiatives in Sales Organizations," Journal of Marketing Theory and Practice, Vol. 8, No. 2, (Spring, 2000), 37-49. 
mereka menjelaskan entrepreneur banyak diproduksi oleh melalui pendidikan dalam pengelolaan usaha dan metode menganalisis usaha. Pandangan ini menyimpulkan pendidikan kewirausahaan berpengalaman lebih banyak menciptakan pengusaha sukses. Sebab pendidikan memberikan inovasi dan testing kepada sarjana untuk menganalisis peluang dalam mendirikan usaha. ${ }^{33}$ Masyarakat yang tinggal di sebuah kampung terkadang mempunyai insting berwirausaha yang kompetitif dengan masyarakat perkotaan. Sebagai ilustrasi menjamurnya pedagang kuliner di Jakarta yang berasal dari Madura, Lamongan, Wonogiri, Padang, Solo, Tegal dan sebagainya. Mereka mempunyai insting berwirausaha diakibatkan oleh orientasi yang sederhana. Fakta di lapangan menunjukan mayoritas kalangan masyarakat tersebut tidak dibekali skill pendidikan berwirausaha. Insting wirausaha yang baik dan mampu menganalisis peluang dalam masyarakat dengan melakukan aksi secara konkrit tanpa banyak pertimbangan.

Pranata sosial seperti pendidikan pada dasarnya memainkan peran penting dalam menghasilkan manusia-manusia yang berkualitas (Inșan alkamil) di masa depan. Kasuistik tertentu menunjukan tidak selamanya pendidikan kewirausahaan mampu untuk menghasilkan kelompok entrepreneur muda. Sebagai contoh adalah serbuan warung pecel lele dan soto Lamongan ke segenap penjuru Nusantara. Penulis dalam hal ini tidak hanya menemukan pedagang Lamongan yang hanya berjualan di Surabaya atau Jawa Timur. Melainkan di sebagian besar kota besar yang terdapat di Kalimantan dan berbagai daerah di Indonesia seperti Jakarta. Migrasi masyarakat desa telah merubah sistem mata pencaharian dari petani menjadi wirausaha. ${ }^{34}$

Tanpa dibekali dengan keahlian dalam bidang berwirausaha di daerah perantauan, khususnya di Jakarta. Evolusi sosio kultural meliputi seluruh komponen suatu masyarakat dimana transformasi awal diakibatkan oleh adanya perubahan sistem yang diwali oleh sebuah komponen yang berdampak pada komponen yang lain. ${ }^{35}$ Bambang Pranowo (2009), menyatakan adanya tingkat frenkuensi yang terkait dengan pasar yang disertai dengan tingkat kepemilikan lahan. Mengakibatkan terjadinya

${ }^{33}$ Paul Tracey and Nelson Phillips, "The Distinctive Challenge of Educating Social Entrepreneurs: A Postscript and Rejoinder to the Special Issue on Entrepreneurship Education," Academy of Management Learning \& Education, Vol. 6, No. 2 (Jun, 2007), 264-271.

34 Chee-Beng Tan and Yuling Ding, "Rural Urbanization and Urban Transformation in Quanzhou, Fujian," Canadian Anthropology Society, Vol. 50, No. 2 (2008), 215-227.

${ }^{35}$ Stephen K Sanderson, Makro Sosiologi Sebuah Pendekatan Terhadap Realitas Sosial (Jakarta: PT Raja Grafindo Persada, 2000), 64-65. 
aktivitas berskala besar yang pada akhirnya menyebabkan kemajemukan profesi masyarakat Jawa. ${ }^{36}$

Menurut Spencer dan Madinus (1974), metode pengasuhan anak masyarakat desa lebih konservatif dan otoriter. Fenomena ini disebabkan oleh perilaku tradisional yang sangat memegang peranan dalam mempersiapkan anak dalam menuju kedewasaan. Orang tua hanya mengajarkan pengalaman yang telah dialaminya kepada anakanaknya. ${ }^{37}$ Keunikan berbeda justru terjadi di Lamongan yang banyak memproduksi entrepreneur jalanan di Jakarta. Oleh karena itu, yang menjadi pertanyaan adalah apakah institusi kewirausahaan dapat lebih kredibel dalam mencetak entrepreneur dibanding pendidikan kewirausahaan masyarakat Lamongan? Peneliti menyimpulkan bahwa antara pola kehidupan sosial masyarakat Lamongan dengan pranata pendidikan mempunyai homogenitas diantara keduanya. Yakni memproduksi wiraswata yang mengurangi jumlah pengangguran. Hanya saja keduanya mencetak agent of change dengan caranya masing-masing sesuai dengan metode yang mereka terapkan.

Pranata pendidikan mentransformasikan ilmu pengetahuan sesuai dengan bentuk kurikulum yang telah diterapkan. ${ }^{38}$ Sementara masyarakat pedesaan memproduksi kalangan wirausaha dikarenakan pengaruh oleh pola kehidupan dan adat istiadat masyarakat yang bersangkutan untuk menjaga nilai-nilai lokal yang ada. Baik antara instansi pendidikan dan konsep pendidikan yang ditawarkan oleh masyarakat pedesaan mempunyai kesamaan. Yakni mencetak manusia-manusia yang mempunyai kualitas sumber daya manusia yang baik. Pasalnya pencarian kekayaaan bukan hanya karena motivasi kerja. Melainkan karena tugas dan dorongan sosial yang tumbul dari suatu masyarakat. ${ }^{39}$

${ }^{36}$ Kelaziman yang diistilahkan oleh Lambros Comitas (1973: 157-1573), sebagai "kemajemukan pekerjaan" (occupational multiplicity). Bagi warga desa, tidak ada garis batas yang tegas antara kegiatan yang berorientasi desa dengan yang berorientasi pasar. Lihat, Bambang Pranowo, Memahami Islam Jawa (Jakarta: Pustaka Alvabet, 2009), 66.

${ }^{37}$ Nanat Fatir Natsir, Etos Kerja Wirausahawan Muslim (Bandung: Gunung Djati Press: 1999), 33.

${ }^{38}$ Stefano Zamagnisource, "Filosofia The Economy of Communion Project as a Challenge to Standard Economic Theory," Revista Portuguesa De Filosofia, T. 70, Fasc. 1 (2014), 44-60.

${ }^{39}$ Max Weber, The Protestan Ethic and The Spirit of Capitalism (Yogyakarta: Jejak, 2007), 9.

INDO-ISLAMIKA, Volume 5 No. 2 Juli - Desember 2015/1438 | 293 
Sebagian ahli menyatakan kewirausahaan merupakan bakat yang dibawa seseorang sejak mereka lahir dan dapat diajarakan. ${ }^{40}$ Anggapan tersebut tidaklah benar, sebab pengertian kewirausahaan bukanlah bakat yang dibawa oleh manusia sejak lahir. Melainkan berkaitan erat dengan pengetahuan dan tindakan yang dilakukan. Pengertian kewirausahaan merupakan definisi yang dijelaskan oleh para ahli. Mereka mendefinisikan sesuai dengan perspektif masing-masing. Terkadang manusia yang dibesarkan dalam lingkungan kewirausahaan tidak mampu untuk tumbuh menjadi seorang wirausahawan. Sebagai contoh tentang pendirian pranata yang berorientasi pada dunia usaha tidak selamanya memproduksioutputnya menjadi entrepreneur.

Kondisi masyarakat Lamongan bilamana ditinjau dari perspektif sosiologis yang berdomisilidi area udik bisa dikatakan sulit untuk menghasilkan wirausahawan. Umumnya mereka hidup berkaitan erat dengan alam seperti pertanian dan perikanan. Masyarakat Lamongan tidak mempunyai pendidikan berwirausaha sebagaimana yang diedukasikan oleh pranata-pranata sosial yang berorientasi menciptakan wirausahawan. Merupakan hal yang unik ketika mayoritas orang Lamonganmemutuskan menjadi seorang wirausahawan kelas kaki lima di Jakarta.

Masyarakat Lamongan yang hidup didaerah yang tandus seakan-akan merasa dibesarkan untuk menjadi penjual soto atau pecel lele. Penulis menemukan kasus bahwa mayoritas dari mereka masih dalam tataran pendidikannya yang rendah. Salah seorang wirausahawan soto yang berhasil hanya lulusan SMP. Perubahan sosial memberikan dampak berupa perubahan sistem mata pencaharian masyarakat. Oleh karena itu, dalam artikel ini, penulis sengaja mengangkat tentang migrasi, kewirausahaan dan ekspresi keagamaan orang Lamongan di Jakarta.

\section{B. Pola Migrasi dan Interaksi Sosial Orang Lamongan di Jakarta}

Orang Lamongan pada awalnya bermigrasi ke Jakarta bukan bekerja dalam sektor usaha kulinet seperti saat ini. Generasi rantau masyarakat Lamongan ke Jakarta banyak didominasi oleh masyarakat yang berasal dari pedesaan khususnya yang wilayahnya sangat tandus. Sangat minim masyarakat Lamongan yang tinggal di perkotaan Lamongan yang menjadi pusat pemerintahan dan perekonomian bermigrasi meninggalkan kampung halaman mereka.

Petani di Lamongan hanya mampu menanam padi sekali dalam setahun, yakni ketika musim penghujan tiba. Karena peranan keadaan iklim

${ }^{40}$ Sukamdani Sahid Gitosarjono, Bisnis dan Kewirausahaan Syariah: Upaya Menuju Kesejahteraan Umat Islam (Bogor: Sekolah Tinggi Agama Islam Terpadu Modern Sahid, 2012), 25. 
untuk pertanian sangat penting dalam aktivitas pertanian. ${ }^{41}$ Pada waktu musim kemarau dimanfaatkan oleh para petani untuk berladang serta menanami sawahnya dengan tembakau atau tanaman yang tidak membutuhkan banyak air. Petani yang menanam tembakau pada musim kemarau menyiasatinya dengan membuat sumur di sekitar sawahnya. Sumur tersebut dimanfaatkan airnya untuk menyirami tembakau yang mereka tanam. Masyarakat Lamongan mempunyai sebuah ungkapan untuk menggambarkan kondisi geografis wilayahnya "nek udan kebanjiran, nek ketigo kepanasan". Ungkapan ini mempunyai arti ketika musim penghujan kebanjiran dan ketika musim kemarau kepanasan. ${ }^{42}$

Tidak bisa dikesampingkan bahwa kondisi geografis turut berperan serta dalam membentuk diferensiasi budaya. ${ }^{43}$ Kebudayaan masyarakat pedesaan tentu berbeda dengan kebudayaan yang ada dalam masyarakat perkotaan.Warga di Kabupaten Lamongan yang tidak memiliki sawah untuk bertani atau tambak untuk membudidayakan ikan, akan mengadu nasib dengan merantau ke kota-kota besar di Indonesia seperti Jakarta, Surabaya dan kota-kota besar lainnya diluar pulau Jawa. Ketiadaan lahan pertanian inilah diantara faktor utama yang menjadi penyebab perilaku merantau warga Lamongan. Konsep bekerja keras dan menghindari sikap menganggur menjadi motivasi utama masyarakat Lamongan ketika merantau. Ketiadaan sawah menyebabkan mereka merantau daripada menganggur di kampung halamannya.

Para perantau dari Lamongan tidak hanya di dominasi oleh orangorang yang tidak mempunyai sawah. Mereka yang memiliki tanah garapan untuk bercocok tanam terkadang enggan untuk memilih profesi sebagai petani. Generasi muda di Lamongan tidak lagi tertarik bekerja sebagai petani yang mereka anggap akan menurunkan status sosialnya. Bekerja sebagai petani secara matematis dalam pandangan mereka tidak sesuai dengan harapan. Banyaknya biaya dan tenaga yang dikeluarkan untuk bertani serta minimnya hasil yang didapat ketika musim panen. Menyebabkan warga Lamongan memutuskan untuk merantau dengan memilih profesi selain petani. Kondisi alam yang tandus serta dorongan yang kuat untuk meninggalkan kampung halaman, baik itu karena alasan gengsi ataupun menganggur guna mencari penghidupan yang lebih baik. Menjadi salah satu alasan yang menyebabkan perilaku merantau orang Lamongan.

${ }^{41}$ Jurgen Honhholz, Geografi Pedesaan (Jakarta: PT Karya Unipress, 1986), 35.

${ }^{42}$ Wawancara dengan Masdi (Lamongan, 2014).

43 Perkuliahan umum agama dan perubahan sosial oleh Prof. Bambang Pranowo setiap Senin jam 08.00-10.00 SPS UIN Syarif Hidayatullah Jakarta

INDO-ISLAMIKA, Volume 5 No. 2 Juli - Desember 2015/1438 | 295 
Jakarta sebagai kota metropolitan merupakan daerah perkotaan besar dalam segi pembangunan ekonomi dengan letak yang tak jauh dari Kabupaten Lamongan. Sarana dan prasarana di Jakarta lebih baik dibandingkan dengan Lamongan. Lapangan pekerjaan dikota terbesar di Indonesia ini juga sangat heterogen. Tergantung potensi dan skill yang dimiliki oleh masyarakat migran dalam menentukan pekerjaannya. Mata pencaharian penduduk kota Jakarta yang identik dengan non pertanian menjadi pertimbangan utama masyarakat Lamongan yang tidak tertarik bekerja sebagai petani. Kondisi tersebut memungkinkan para pemuda yang merantau ke Jakarta berspekulasi bahwa kehidupan di Jakarta akan lebih baik daripada di Lamongan. Warga yang merantau ke Jakarta bekerja dalam berbagai macam sektor perekonomian. Tergantung dari kemampuan serta keterampilan yang mereka miliki.

Interaksi sosial orang Lamongan yang berdomisili di perkotaan mempunyai distingsi dengan masyarakat yang berada di pedesaan. Lingkungan sosial perkotaan yang bebas dan tidak mempunyai kontrol sosial yang kuat dianggap sebagai sebuah sarana dalam mengembangkan potensi. Pola interaksi orang Lamongan yang berdomisili di perkotaan dibentuk oleh warga yang berasal dari desa atau daerah yang berbeda. Orang Lamongan senantiasa berinteraksi dengan orang Lamongan yang berasal dari sebuah perkampungan yang berbeda dengan yang lainnya. Sangat jarang sekali orang Lamongan yang berinteraksi secara cooperation dengan sesama pendatang dari Lamongan yang berasal dari pedesaan yang sama.

Pola kehidupan orang Lamongan di Jakarta biasanya berkaitan erat dengan masyarakat Lamongan yang berasal dari daerah lain. Konstruk solidaritas mekanik berlaku bagi masyarakat Lamongan pada kasus yang demikian. Secara umum, mereka akan membentuk sebuah interaksi sosial yang bersifat asosiatif dalam bentuk kerja sama sebagai kohesi sosial satu sama lain. Tindakan ini dilakukan untuk menghindari kontrol sosial yang begitu kuat. Orang Lamongan tidak tertarik membentuk pola ikatan kerja dengan masyarakat Lamongan yang berasal dari sebuah pedesaan yang sama. Warga Lamongan mempunyai kecenderungan untuk menghindar dari sesama komunitas yang berasal dari pedesaan yang sama.

Motif yang demikian menjadi sebuah pertimbangan penting dalam menjalankan aktivitas kehidupan mereka selama tinggal di Jakarta. Apabila mereka bertemu dengan sesama keluarga atau anggota masyarakat yang berasal dari pedesaan yang sama. Tindakan yang dilakukan adalah dengan menghindar agar bebas dalam mengembangkan karir selama tinggal di Jakarta. Proses ketika meniti jalan kehidupan adalah sebuah fase yang dilalui oleh seseorang untuk mendapatkan apa yang mereka inginkan. Mobilitas sosial orang Lamongan selama tinggal di Jakarta terjadi melalui sebuah pola interaksi sosial dengan warga yang berasal dari daerah yang berbeda. 
Pemahaman nilai-nilai kehidupan yang diajarkan oleh orang tua mereka membentuk perilaku selama mereka tinggal di Jakarta. Warga Lamongan yang belum mencapai kemapanan hidup dalam mobilitas sosial ekonomi lebih bersikap menghindar dari sesama warga Lamongan yang berasal dari pedesaan yang sama. Tingginya gengsi atau sikap tidak ingin menurunkan status sosial (social sinking) adalah diantara faktor yang menyebabkan orang Lamongan berinteraksi secara demikian. Selama menjalani proses kehidupan sebagai solusi memperbaiki kehidupan ekonomi. Menghindari diri dengan bergaul dengan sesama komunitas yang berasal dari perkampungan yang sama adalah upaya untuk menjaga status sosialnya.Kalangan orang tua dalam keluarga lebih bersikap selektif terhadap anak-anak mereka selama tinggal di Jakarta. Sikap yang enggan dilakukan oleh anak adalah pantang untuk membantah wejangan yang orang tua. Anggapan adanya sanksi magis berupa kuwalat merupakan manifestasi sebuah kontrol sosial yang efektif untuk mendorong anak agar mematuhi orang tua. Struktur pendidikan dimanifestasikan dalam bentuk interaksi sosial berupa sopan-santun atau tata karma (unggah-ungguh). ${ }^{44}$

Tindakan yang dilakukan oleh orang tua adalah menjaga jarak dengan sesama keluarga yang mempunyai keretakan sosial karena faktor ekonomi atau status sosial. Sikap orang tua dalam menjaga kewibawaan keluarga adalah bersikap sangat selektif kepada anak-anaknya ketika berinteraksi sosial. Bentuk penghormatan atau penghargaan tinggi yang diberikan oleh anggota keluarga yang telah menetap di Jakarta adalah sebagai sebuah magnet yang menjadi intensitas dalam mengkonstruk solidaritas sosial. Sikap orang tua tidak membatasi pergaulan anak-anaknya dengan sesama keluarga atau orang yang berasal dari pedesaan yang sama ketika mereka merasa dihormati atau dihargai. Istilah ini dalam bahasa Jawa disebut nguwongno wong atau menghargai dan menghormati orang lain.

Perubahan masyarakat dalam bidang ekonomi dari sektor agraris ke wirausahawan telah mengkonstruk migrasi masyarakat Lamongan dalam transformasi sosial dari tradisional menuju modern. Struktur sosial secara langsung maupun tidak langsung akan mengalami sebuah perubahan. Ngenger merupakan sebuah mobilitas sosial kelas tradisional. Bentuk mobilitas social geografis yang terjadi pada masyarakat Jawa. Ngenger dimaknai sebagai sebuah mobilitas sosial vertikal yang biasa dilakukan kalangan petani kepada sektor lain di Jawa. Migrasi merupakan sebuah

44 Sartono Kartodirjo, A. Sudewo dan Suhardjo Hatmosuprobo, Perkembangan Peradaban Priayi (Yogyakarta: Gadjah Mada University Press, 1993), 100-101.

INDO-ISLAMIKA, Volume 5 No. 2 Juli - Desember 2015/1438 | 297 
mobilitas manusia dari satu tempat ke tempat yang lain dalam upaya untuk merubah status dan struktur sosial. ${ }^{45}$

Akumulasi kekayaan atau pencapaian orang Lamongan dalam bidang ekonomi selama tinggal di Jakarta tidak menjadi sebuah kohesi sosial bagi para migran lainnya. Keluarga yang belum mencapai kemapanan dalam kehidupan ekonomi tidak menjadikan anak-anak mereka sebagai tenaga kerja. Upaya yang dilakukan oleh orang tua adalah dengan menyuruh anakanaknya bekerja kepada orang lain. Selama bekerja mereka mempunyai kebebasan dan merasa tidak diperlakukan sebagai seorang karyawan oleh keluarganya sendiri. Para orang tua di Lamongan lebih menyukai ketika anak-anak mereka menjadi karyawan orang lain daripada keluarga sendiri.Salah seorang warga Lamongan menuturkan bahwa menjadi karyawan orang lain lebih menyenangkan daripada menjadi karyawan bagi keluarga sendiri. Adnan yang bekerja sebagai karyawan soto dan pecel lele Lamongan menuturkan "bekerja pada orang lain lebih bebas daripada bekerja ikut keluarga sendiri" ${ }^{46}$ Deksripsi tersebut lebih mengedepankan status sosial daripada kebebasan dalam menjalankan usaha.

Sarana dan prasarana lengkap ketika seseorang berdomisili di Jakarta termasuk indikator yang memberikan kebanggaan tersendiri. Seorang guru yang tinggal di Lamongan mempunyai status sosial yang rendah dengan seorang kuli yang tinggal di Jakarta. Eskalasi waktu mudik merupakan sebuah indikator yang menjadikan masyarakat Lamongan yang tinggal di Jakarta jarang sekali mudik. Keberadaan kereta cepat JakartaSurabaya tidak menjadikan arus mudik Lamongan Jakarta berlangsung setiap beberapa bulan sekali. Keengganan pulang adalah sebagai bentuk menghindari status sosial yang belum mapan bagi masyarakat Lamongan.Masyarakat migranyang berpendidikan rendah mayoritas bekerja di sektor informal yang tidak membutuhkan kualifikasi tingkat pendidikan. Mereka mengembangkan skill dan potensinya pada sektor informal yang tidak mempunyai ijazah. Kerja serabutan pada umumnya merupakan bentuk kerja paramigran yang mempunyai tingkat pendidikan yang rendah. Golongan yang demikian mengalami banyak kendala ketika melamar pekerjaan dalam sebuah perusahaan yang lebih menitiberatkan aspek pendidikan daripada skill. Warga Lamongan yang berpendidikan rendah ketika bermigrasi ke kota-kota besar karena inisiatif sendiri secara umumtermotivasi berwirausaha. ${ }^{47}$

45 Suwardi Endraswara, Etnologi Jawa: Penelitian, Perbandingan, dan Pemaknaan Budaya (Yogyakarta: Center for Academic Publishing Service, 2015), 171-172.

${ }^{46}$ Wawancara dengan Adnan, karyawan soto Lamongan.

${ }^{47}$ Wawancara dengan Sujiyanto (Jakarta, Oktober 2015). 
Menurut Weber sebuah realitas sosial merupakan hasil dari pengalaman hidup manusia. Weber mempunyai asumsi dasar tentang manusia. Pertama, realitas sosial merupakan hasil dari pemaknaan subjektif. Kedua adalah asumsi Durkheim bahwa masyarakat merupakan realitas objektif sebagaimana sebuah fakta. ${ }^{48}$ Ada beberapa faktor yang menyebabkan orang Lamongan lebih intens berinteraksi dengan warga Lamongan yang berasal dari pedesaan atau perkampungan yang berbeda karena kebebasan dalam menjalankan aktivitas, menghindari kontrol sosial yang ketat, serta menghindari proses dalam meniti karir.

Tindakan tersebut dilakukan agar selama meniti karir tidak diketahui oleh sesama warga yang berasal dari perkampungan yang sama. Mereka biasanya berinteraksi sosial ketika sudah mencapai kemapanan dalam di Jakarta. Orang Lamongan lebih senang mendirikan usaha dengan orang yang berasal dari luar desa atau perkampungan mereka. Segala sesuatu yang berhubungan dengan aktivitas selama di Jakarta tidak dibawa ke kampung halaman. Selain itu, digunakan sebagai sarana dalam menghindari gunjingan sosial ketika mereka kembali ke kampung halaman mereka.Pola jaringan kewirausahaan masyarakat Lamongan terbentuk dari keluarga yang berasal dari seayah atau seibu. Jarang sekali mereka membentuk wirausaha dari saudara yang sudah terpisah antara ayah dan ibu. Pola yang terpisah biasanya menyebabkan kompetisi secara disasosiatif dalam bidang ekonomi diantara keluarga. Pola yang demikian tidak hanya terjadi dalam dunia kewirausahaan. Melainkan dalam bentuk kompetisi lainnya.

\section{Korelasi Agama dengan Wirausaha}

Aspek keagamaan orang Lamongan di Jakarta dikonstruksioleh kesadaran diskursif individu untuk menjalankan aktivitas keagamaan. Kondisi ini berbeda dengan kehidupan masyarakat Lamongan yang berada di daerah asalnya. Kegiatan kegaamaan terdorong bukan karena adanya kesadaran dari dalam. Melainkan kesadaran diskursif yang mempengaruhi warganya untuk mengekspresikan aktivitas keagamaan secara komunal. Agama bagi masyarakat Lamongan yang tinggal di daerah asalnya merupakan bagian kontrol sosial yang membentuk perilaku warganya. Namun bagi migran Lamongan di Jakarta, agama adalah sebuah kewajiban yang bersifat personal.

Sebagaimana masyarakat Jawa pada umumnya masih menekankan agar anak-anak mereka bekerja pada sektor pemerintahan atau swasta daripada berwirausaha. Adanya pendapatan yang stabil dengan gaji bulanan yang tetap menjadi sebuah pertimbangan penting dalam orientasi bekerja di

${ }^{48}$ Geger Riyanto, Peter L Berger Perspektif Metateori Pemikiran (Jakarta: LP3ES, 2009), 72.

INDO-ISLAMIKA, Volume 5 No. 2 Juli - Desember 2015/1438 | 299 
pemerintahan atau swasta daripada berwirausaha dengan resiko incomeyang tidak pasti. Berwirausaha hanya menjadi sebuah alternatif ketika dihadapkan dengan kemungkinan yang minim dalam menempuh karir di pemerintahan atau swasta karena tidak mempunyai latar belakang pendidikan yang sesuai dengan persyaratan yang telah ditentukan.

Kewirausahaan masyarakat Lamongan tidak hanya dibentuk oleh motivasi berprestasi (need of achievement) untuk meningkatkan status sosialnya. Suatu masyarakat mengalami perkembangan dan kemajuan ketika ditengah-tengah masyarakat ada seorang tokoh atau beberapa tokoh yang memberikan pengaruh. Pesan-pesan moral para tokoh agama atau tokoh masyarakat membentuk pola kehidupan khusus yang menentukan arah transformasi sosial.Masyarakat yang hidup dalam kebiasaan skeptis pada umumnya dikarenakan peranan tokoh agama yang membentuk pola kehidupan yang demikian. Orientasi dan motivasi kehidupan digambarkan sebagai sesuatu yang menjauhi kehidupan dan kemewahan duniawi. Etos kerja masyarakat yang pola kehidupannya pada pemberian yang bersifat apa adanya dapat menyebabkan etos kerja yang rendah. Bagi mereka, orientasi kehidupan didasarkan pada pola kehidupan sederhana dan apa adanya.

Pola kehidupan skeptic masyarakat yang demikian masih terjadi pada beberapa masyarakat Indonesia yang hidup di daerah-daerah yang menjunjung tinggi nilai dan kehidupan yang sederhana. Kompetisi ekonomi pada masyarakat yang demikian terjadi secara longgar. Indikasi pengakuan sosial bukan didasarkan pada reifikasi sosial yang berorientasi pada akumulasi materi. Kesederhanaan dengan menaati norma-norma dan nilainilai sosial menjadi sebuah indikator dalam perilaku sosial masyarakatnya. Mayoritas masyarakat yang hidup dalam kesederhaan menjadi penyebab bagi para warganya untuk tetap nyaman ketika menetap di kampung halaman mereka. Umumnya mereka mempunyai mata pencaharian sebagai petani dan nelayan yang identik dengan meanfaatkan komoditas alam.Sistem kehidupan masyarakat yang demikian umumnya bermigrasi karena dorongan untuk mencari pengetahuan serta mengembangkan karir di daerah tujuan. Status sosial ditentukan bukan karena akumulasi kekayaan semata, melainkan dari pengetahuan serta keterampilan yang mereka dapatkan. Pola migrasi masyarakat ini karena dilatar belakangi oleh motivasi pendidikan dan pengetahuan.

Budaya priayi pada masyarakat Jawa tidak menggolongkan masyarakat kedalam strata sosial berdasarkan akumulasi kekayaan semata. Namun berdasarkan peran mereka di masyarakat atau pemerintahan. Peran priayi yang dijalankan oleh masayarakat Jawa tidak hanya sebatas peran dalam aspek pemerintahan. Jabatan tinggi dalam suatu perusahaan atau eselon menjadi prestise tersendiri bagi mayoritas masyarakat Jawa. Ilustrasi yang demikian menggambarkan bahwa pola struktur sosial masyarakat Jawa

300 | INDO-ISLAMIKA, Volume 5 No. 2 Juli - Desember 2015/1438 
bukan ditentukan oleh akumulasi kekayaan semata. Namun di dasarkan pada peran dan kontribusi mereka di tengah masyarakat.

Perkembangan kedudukan seorang aristokrat diperkuat dengan adanya tiga aspek yang mendasarinya. Adanya perkembangan tersebut memperkuat kedudukan kaum aristokrat yang memegang kendali pemerintahan. Karena adanya orientasi untuk memegang teguh kepada status, tradisi dan prefigurasi. Ketiga pokok orientasi tersebut berkaitan antara satu sama lain serta adanya saling ketergantungan. Bagi kelompok yang mapan kedudukannya, mempunyai kecenderungan untuk mempertahankan kedudukan status sosialnya untuk lebih kuat. Sebuah asumsi logis ketika status menjadi kriteria untuk suatu konservatisme. Masyarakat tradisional mempunyai budaya yang mendukung kultus serta simbol-simbol yang mendukung ekspresi dan gaya hidup priayi. ${ }^{49}$ Bagi masyarakat yang asketis, pola kehidupan yang didasarkan pada reifikasi sosial cenderung mengarah pada akumulasi kekayaan. Individu serta entitas yang ada di dalamnya mengalami sebuah gejolak atau culturallag. Pada umumnya, masyarakat yang demikian bermigrasi karena dilatarbelakangi oleh motivasi ekonomi. Generasi muda ketika memasuki usia yang produktif memilih meninggalkan kampung halamannya untuk memperbaiki kondisi perekonomiannya. Umumnya mereka tidak nyaman untuk tinggal di kampung halaman karena transformasi sosial.

Budaya yang menjadi sebuah sarana meningkatkan status sosialnya menjadi alasan utama bermigrasi masyarakat yang dmikian. Latar belakang kondisi sosial yang tidak didasarkan pada penataan terhadap nilai-nilai dan norma-norma sosial. Masyarakat menganggap bahwa keadaan tidak mempunyai pekerjaan (tuna karya) adalah sesuatu yang dapat menurunkan status sosialnya di tengah-tengah masyarakat. Pola kehidupan masyarakar pada tahun sebelum memasuki abad kedua puluh masih bersisat skeptis. Kesederhanaan dan akumulasi materi tidak menjadi indikator yang penting ditengah-tengah masyarakar. Mereka menilai ukuran status sosial bukan ditentukan oleh kepemilikan materi. Namun karena pola perilaku dalam mentaati nilia-nilai dan norma-norma sosial di tengah masyarakat. Pada fase ini, masyarakat Lamongan senantiasa hidup dalam kesederhanaan dan tidak menonjolkan kekayaan.

Para tokoh agama yang belum mempunyai kemapanan dalam kehidupan ekonomi senantiasa menonjolkan kehidupan sederhana. Metode pembelajaran yang demikian kemudian memberikan pengaruh terhadap gaya hidup masyarakat yang cenderung berorientasi pada kesederhanaan. Sementara pada tahun dua ribu ke-atas, pola kehidupan tokoh agama yang

\footnotetext{
${ }^{49}$ Sartono Kartodirjo, A. Sudewo dan Suhardjo Hatmosuprobo, Perkembangan Peradaban Priayi (Yogyakarta: Gadjah Mada University Press, 1993), 72.
} 
mempunyai kemapanan dalam kehidupan ekonomi lebih menuruti gaya hidup yang mewah dan kurang menonjolkan aspek kesederhanaan. Pengajian yang disodorkan pada masyarakat lebih berorientasi pada kemampuan dalam pencapaian ekonomi senantiasa mereka angkat di permukaan umum sebagai legitimasi bahwa seseorang yang mendekat kepada tuhan diberikan kekayaan.Ukuran kasih sayang tuhan kepada manusia pada dasarnya merupakan konsep etika protestan (the spirit of capitalism and protestan ethic) yang dikemukakan oleh Max Weber. Bagi masyarakat yang mempunyai kekayaan yang melimpah dan kemampuan dalam pencapaian ekonomi yang mapan. Tentu konsep yang demikian tidak menjadi problematika bagi masyarakat yang mempunyai kemapanan dalam hidup. Sementara bagi masyarakat yang belum mempunyai kemampuan dalam kemapanan ekonomi bersikap sebaliknya.

Komunitas masyarakat yang mempunyai kehidupan ekonomi yang baik senantiasa berhimpun dengan masyarakat yang mempunyai kemapanan. Termasuk yang dilakukan oleh para pemuka agama yang cenderung hanya berkumpul dengan komunitas yang sama dalam kemapanan. Masyarakat yang merasa termarjinalkan cenderung untuk bekerja keras agar mempunyai status sosial yang sama di tengah masyarakatnya. Upaya yang mereka lakukan adalah dengan merubah pola kehidupan yang awalnya bergantung dengan kondisi alam dengan merantau atau bermigrasi.Masyarakat Lamongan mempunyai sebuah kepercayaan bahwa pola kehidupan yang monoton di desa tidak benyak mempengaruhi prospek kehidupannya. Dalam pandangan sebagian besar masyarakat Lamongan, pola kehidupan yang monoton hanya menghambat kemajuan pola pikir dan kehidupan perekonomian. Upaya yang dilakukan oleh masyarakat Lamongan yang merasa tidak nyaman ketika tinggal di kampung halaman mereka adalah dengan bermigrasi.

Jakarta merupakan kota metropolitan yang menjadi destinasi utama masyarakat Lamongan. Gaya hidup yang bebas disertai dengan kontrol sosial yang renggang menjadi pertimbangan tersendiri bagi warga Lamongan. Pola kontrol sosial yang renggang merupakan sebuah keleluasaan dalam mengembangkan karir di masa depan. Ruang gerak yang bebas di perkotaan menjadi sebuah nilai tambah dalam mengembangkan kehidupan yang lebih baik di Jakarta.

Kehidupan yang monoton disertai dengan kontrol sosial yang ketat dianggap sebagai hambatan dalam mengembangkan aktivitas dimasa depan. Masyarakat senantiasa menilai dan mengawasi aktivitas seseorang di pedesaan. Upaya yang dilakukan oleh masyarakat dengan adalah dengan memberikan kontrol sosial yang ketat. Fenomena ini memberikan gambaran bahwa masyarakat pedesaan sukar untuk dipisahkan dengan aktivitas pertanian. Bekerja sebagai petani memberikan nilai tambah dalam benak 
sebagian masyarakat. Sebab aktivitas yang demikian dilakukan secara bersamaan dengan warga masyarakat lainnya.

Berbeda dengan masyarakat yang bekerja sebagai seorang pedagang yang mengirimkan barang dagangannya keluar desa. Steorotip yang diberikan masyarakat kemudian menimbulkan sebuah anggapan yang kurang baik karena mereka tidak mengetahui aktivitas yang dijalankan oleh pedagang. Kondisi yang demikian diperparah dengan kehidupan pedagang yang belum mencapai kemapanan dalam kehidupan ekonomi.Masyarakat desa yang mempunyai pekerjaan di kota (forensen) memulai aktivitas di pagi hari dengan sistem pulang-pergi dari desa ke kota. Istilah yang demikian dalam bahasa Jawa di kenal dengan sebutan ngalong, yakni pulang-pergi dalam memulai aktivitas bekerja. Selain sebagai hinterland atau penyangga kehidupan masyarakat perkotaan, pola kehidupan masyarakat desa juga memberikan kontribusi dalam penyangga aktivitas sosial pemerintahan dan perekonomian. Eksistensi desa tidak hanya memberikan kontribusi dalam bentuk sumber daya alam, melainkan sebagai penyuplai kebutuhan masyarakat perkotaan dalam sektor pekerjaan.

Keberadaan usaha kecil yang dijalankan oleh orang Lamongan secara tidak langsung memberikan kontribusi dalam mengurangi jumlah pengangguran di Jakarta. Adanya hambatan yang dialami oleh sebagian besar pedagang kecil yang terdapat di Jakarta. Tidak menjadi hambatan yang berarti bagi ekspansi usaha sektor kuliner warga Lamongan di Jakarta. Keberadaan warung-warung milik warga lamongan di Jakarta juga mampu untuk memberikan kontribusi dalam mengurangi problem sosial pengangguran.

Pengangguran yang diakibatkan oleh minimnya lapangan pekerjaan menjadi tanggung jawab penting bagi pemerintah dalam upaya mengurangi problem sosial yang demikian. Warung-warung Lamongan senantiasa menyerap jumlah tenaga kerja yang berasal dari berbagai daerah atau sekitar tempat usaha yang mereka jalankan. Mereka mampu menggaji karyawan RP. 900.000-1.000.000 perbulan untuk setiap karyawan tergantung jumlah pemasukan dan keuntungan yang di dapatkan.Mangkraknya proyek yang dijalankan oleh pemerintah terkadang memberikan dampak yang cukup signifikan terhadap kelangsungan usaha kecil di Jakarta. Arif merupakan diantara warga Lamongan yang menjalankan usaha kuliner di Jakarta selatan. Adanya proyek jembatan layang yang digarap dalam waktu yang lama oleh pemerintah memberikan dampak dalam omset bulanan. Sebelum dibangunnya jembatan layang, Arif mampu memperoleh pendapatan Rp. 5.000.000perhari dalam jumlah rata-rata. Namun setelah dibangunnya jembatan layang yang tidak kunjung selesai, jumlah pendapatannya rata-rata perharinya Rp. 3.000.000 perhari. "saya sekarang hanya mampu mendapatkan keuntungan sebesar tiga juta permalam. Pada waktu yang lalu saya sebelum

INDO-ISLAMIKA, Volume 5 No. 2 Juli - Desember 2015/1438 | 303 
dibangunnya jembatan layang, saya bisa mendapatkan keuntungan bersih sebanyak lima juta rupiah perhari”

Ketahanan usaha kecil dalam menghadapi hambatan dan krisis ekonomi lebih kuat dibandingkan dengan usaha yang brskala besar. Sektor non-formal ini mampu bertahan ditengah terpaan krisis ekonomi di Indonesia. Ketika usaha yang lain banyak yang gulung tikar dalam menghadapi krisis, sektor kuliner yang dijalankan orang Lamongan masih bertahan dalam kondisi apapun. Ditengah program pemerintah dalam upaya mengurangi jumlah pengangguran dengan menyedikan lapangan pekerjaan baru. Entrepreneurship dianggap sebagai problemsolving untuk mereduksi pengangguran. Para migran yang bergerak dalam sektor informal dengan mendirikan kewirausahaan dapat memberikan kontribusi dalam memperkecil jumlah pengangguran. Keberadaan masyarakat dari golongan bawah mereka tampung sebagai tenaga kerja tanpa menekankan pada tinggi rendahnya aspek pendidikan.

Kondisi bekerja sebagai karyawan atau pegawai menjadi problem kultural bagi masyarakat Lamongan lainnya. Mereka memaknainya dengan anggapan bahwa bekerja menjadi wirausaha mempunyai lebih banyak waktu luang dan kebebasan dalam menjalani hidup. Sementara bekerja di sebuah perusahaan dan pemerintahan hanya membatasi diri dengan aturan-aturan yang berlaku. Pandangan ini diperkuat dengan fluktuasi income yang di dapatkan dalam periode tertentu, yakni dengan pendapatan perhari. Wirausahawan Lamongan mempunyai sebuah asumsi bahwa bekerja diperkantoran membatasi diri mereka.

Bila diperhatikan dengan seksama, orang Lamongan yang tinggal di Jakarta mempunyai tingkat perbedaan yang mencolok dengan yang berdomisili di pedesaan. Mereka menjalankan peribadatan sebagai bentuk kewajiban yang harus mereka penuhi termasuk sholat lima waktu. Sedangkan masyarakat Lamongan yang tinggal di pedesaan dalam menjalankan kegiatan keagamaan lebih dipengaruhi oleh kehidupan lingkungan sekitarnya. Pola kehidupan masyarakat Jawa yang tinggal di pedesaan mempunyai perbedaan dengan perkotaan. Masyarakat desa pada umumnya menjadikan sarung sebagai identitas untuk menampilkan perilaku keagamaan. ${ }^{50}$

\section{Ekspresi Keagamaan Orang Lamongan di Jakarta}

Warga di Lamongan ketika mengarahkan anak-anak mereka bekerja sebagai karyawan di sektor kuliner lebih bersikap seletif dan tidak

${ }^{50}$ Denys Lombard, Le Carrefour Javanais (Paris: Ecole des Hautes Etudes en Sciences Sociales, 1990). Diterjemahkan oleh, Winarsih Partaningrat Arifin dkk, Nusa Jawa: Silang Budaya Kajian Sejarah Terpadu (Jakarta: Gramedia Pustaka Utama), 156-157. 
sembarangan. Tindakan ini dilakukan agar anak-anak mereka bisa terjaga dan terbimbing selama tinggal di Jakarta. Biasanya orang tua menyukai jika anak-anak mereka ikut pada orang Lamongan yang membuka warung-warung di Jakarta yang mempunyai pemahaman dan penerapan agama yang baik. Dari sini bisa terlihat bahwa orientasi yang dibangun bukan hanya pada akumulasi kekayaan semata. Namun proteksi dari pengaruh dunia luar yang membawa dampak negatif selama tinggal di Jakarta.Warga yang tinggal di Lamongan berbeda dengan yang berdomisili daerah perantauan. Khususnya yang tinggal di daerah Jakarta sebagai kota terbesar di Indonesia yang heterogen. Orang Lamongan yang berdomisili di daerah perantauan lebih terbuka daripada yang tinggal di daerah asalnya. ${ }^{51}$ Umumnya etos kerja warga yang tinggal di daerah perantauan lebih tinggi daripada mereka yang tinggal di kampung halamannya.

Pualam merupakan organisasi sosial yang didirikan oleh masyarakat Lamongan sebagai wadah perkumpulan dalam menjalankan silaturrahmi. Paguyuban ini didirikan atas inisiatif tokoh-tokoh Lamongan yang berada di daerah Jabodetabek (Jakarta, Bogor, Depok, Tangerang dan Bekasi). Menurut penuturan orang Lamongan yang merantau lebih dari sepuluh tahun di Jakarta, Pualam mengadakan silaturrahmi di antara warga Lamongan dalam tempo setahun sekali atau ketika ada acara tertentu. Mereka biasanya mengadakan acara ini di anjungan Jawa Timur Taman Mini Indonesia Indah setelah hari raya.Pualam terdiri dari pedagang soto, pecel lele dan berbagai elemen warga Lamongan yang bekerja dalam berbagai macam sektor di Jakarta. Dalam acara yang diadakan oleh warga Lamongan biasanya dihadiri oleh ribuan migran yang berasal dari Lamongan. Halal-bihalal adalah acara yang diadakan secara rutin oleh warga Lamongan setiap tahunnya. Menurut penuturan Narsim, Pualam mempunyai anggota tetap. Yakni warga Lamongan yang telah bekerja di daerah Jakarta dan sekitarnya selama lebih dari sepuluh tahun. ${ }^{52}$

Formala atau Forum Mahasiswa Lamongan merupakan organisasi yang didirikan untuk mewadahi kegiatan masyarakat Lamongan. Kegiatan yang dijalankan oleh Formala adalah berdiskusi dan kajian ilmiah diantara mahasiswa Lamongan. Pada malam Jum'at mahasiswa Lamongan mengadakan kegiatan manaqiban dan dziba'an yang diamalkan oleh sebagian besar masyarakat Lamongan yang menganut aliran NU. Mahasiswa Lamongan yang mempunyai aliran Muhammadiyah tidak ikut serta dalam mengadakan kegiatan ini. Mereka lebih toleransi terhadap mahasiswa NU.Secara umum, komposisi antara NU dan Muhammadiyah di Lamongan

${ }^{51}$ Wawancara dengan Ramelan (Lamongan, 2014).

52 Wawancara dengan Narsim, seorang pegawai ekspedisi dari Lamongan yang menetap selama lima belas tahun di Jakarta.

INDO-ISLAMIKA, Volume 5 No. 2 Juli - Desember 2015/1438 | 305 
tidak berbeda jauh sebagaimana daerah Jawa Timur pada umumnya yang didominasi oleh kalangan NU. Selain kedua aliran tersebut banyak juga aliran kejawen di Lamongan. Mayoritas tinggal di daerah pegunungan dan pedalaman yang didominasi oleh kalangan petani.

Para migran dari Lamongan yang tinggal di Jakarta mempunyai cara yang berbeda dalam menjalankan aktivitas keagamaannya. Kebanyakan mereka menjalankan peribadatan sesuai dengan kemampuan mereka di Jakarta. Dalam artian tidak terlalu mencolok sebagaimana yang terjadi pada masyarakat Lamongan di daerah asalnya. ${ }^{53}$ Masyarakat Lamongan di daerah asalnya cenderung menjadikan aktivitas keagamaannya sebagai sebuah ritual peribadatan yang terlembagakan. Tindakan ini dilakukan sebagai upaya untuk meningkatkan status sosialnya, bukan menjalankan aktivitas rohani secara esensi. Sikap ingin dihormati adalah model persaingan diantara masyarakat yang ingin menampilkan aktivitas keagamaan ke ruang publik. ${ }^{54}$

Warga Lamongan lebih suka bilamana mereka hidup berdampingan dengan warga yang berbeda perkampungan atau kecamatan. Mereka kebanyakan menjaga jarak dengan orang yang berasal dari daerah atau perkampungan yang sama. Tindakan ini lebih menguatkan diantara mereka untuk bersolidaritas sosial yang pada akhirnya mengikat masyarakat Lamongan. ${ }^{55}$ Perilaku sosial masyarakat migran berubah seperti terlihat dari bentuk arsitektur rumah tinggal, pola hidup bertetangga, apresiasi seni budaya, praktek ekonomi, sikap berorganisasi dan berkelompok dan sebagainya. ${ }^{56}$

Pola interaksi dengan warga Lamongan yang berbeda kecamatan lebih memudahkan mereka untuk bergerak secara leluasa tanpa adanya sebuah kontrol sosial yang kuat diantara masyarakat yang berasal dari pedesaan yang sama. Selama di daerah perantauan, warga Lamongan biasanya tidak mengandalkan pola hubungan dengan warga yang berasal dari pedesaan atau keluarga yang sama. Jaringan wirausaha yang mereka bentuk biasanya berkonstruk dari orang Lamongan yang berasal dari pedesaan atau perkampungan yang berbeda. ${ }^{57}$

Keluarga yang belum suksess dalam menjalankan usaha menjalin mitra dengan teman atau kerabat yang berasal dari pedesaan yang berbeda atau dari

${ }^{53}$ Wawancara dengan Fatoni (Lamongan, Juli 2015).

${ }^{54}$ Etan Diamond, Souls of The City: Religion and the Search for Community in Postwar America (Bloomington: Indiana University Press, 2003),

${ }^{55}$ Wawancara dengan Kiswantoro (Lamongan, Agustus 2015).

${ }^{56}$ Huriyuddin, Pergeseran Kultural di Kampung Urban: Studi di Kampung Pintuair Bekasi Selatan (Jakarta: Badan Litbang Departemen Agama RI, 1997), 42.

${ }^{57}$ Wawancara dengan Adnan (Jakarta, September 2015). 
kecamatan yang jauh. ${ }^{58}$ Kompetisi yang ketat di Jakarta pada akhirnya menimbulkan sebuah seleksi alam secara ketat dalam bentuk kompetisi untuk mencapai kemapanan hidup dalam pemenuhan kebutuhan ekonomi. Menurut Charles Darwin, dunia merupakan sebuah kompetisi besar yang menyebabkan makhluk hidup berkompetisi dalam mencapai kehidupan yang lebih baik. Kaum migran yang terdiri dari berbagai latar belakang masyarakat yang terkonsentrasi di kota-kota besar pada akhirnya melakukan berbagai upaya dalam mencapai sebuah tujuan hidup.

Kalangan orang tua Lamongan yang telah sukses dengan mempunyai anak yang tingkat pendidikannya rendah mengesampingkan aspek pendidikan dalam kehidupan mereka. Motif pencapaian ekonomi merupakan alasan utama yang dijadikan tolok ukur oleh kalangan orang tua di Lamongan sampai saat ini. Tingkat pendidikan yang tinggi tanpa pencapaian ekonomi yang matang hanyalah sebuah pencapaian yang tidak meningkatkan status sosial. Warga Lamongan yang demikian lebih berpikiran pragmatis dalam memahami aspek pengetahuan dan pendidikan. Bilamana seorang hanya mampu berteori tanpa memberikan sebuah bukti yang konkrit menjadi gunjingan dan cemoohan tersendiri bagi masyarakat Lamongan.

Kelompok masyarakat Lamongan yang tinggal di pesisiran mempunyai sebuah filosofi yang unik dalam memandang dunia pendidikan yang belum mampu menciptakan manusia secara matang. Terutama kemapanan dalam pencapaian kehidupan ekonomi. Filosofi masyarakat Paciran adalah "jangan mengajari ikan untuk berenang"yang bermakna jangan mengajari orang yang sudah berpengalaman dan merasakan pahit manisnya asam kehidupan. Sementara masyarakat Lamongan yang tinggal di daerah pegunungan mempunyai sebuah filosofi "jangan mengajari burung untuk terbang" sebab pengalaman mereka dalam kehidupan lebih lama.

Pengalaman sampai saat ini masih menjadi sebuah pembelajaran hidup yang penting bagi sebagian besar masyarakat Lamongan. Terutama pengalaman yang didapatkan di daerah perantauan yang tidak terdapat di kampong halaman sendiri. Jakarta sebagai sebuah kota besar tentu menjadikan penduduknya untuk belajar dan memberikan pengalaman berharga tentunya. Komposisi Jakarta yang multikultur menjadikannya sebagai sebuah kota terpadat dan kompleks di wilayah Indonesia.

Adapun sebab berikutnya yang menjadikan Jakarta sebagai tujuan utama masyarakat Lamongan adalah karena daya tariknya. Infrastruktur yang lengkap serta merasa lebih gengsi bila hidup di kota besar adalah kebanggaan tersendiri bagi masyarakat Lamongan dalam meningkatkan status sosialnya. Selama beberapa tahun mereka tinggal di Jakarta sampai mereka ingin kembali ke kampung halaman mereka sendiri. Ketika seorang pemuda

\footnotetext{
${ }^{58}$ Wawancara dengan Trisno (Jakarta, April 2015).
} 
mempunyai rumah di Jakarta, maka mereka enggan untuk kembali ke kampung halamannya. Teori demikian lebih identik dengan everet S. Lee yang menjadikan motif migrasi yang disebabkan karena daya tarik kota.

Pola keagamaan masyarakat Lamongan yang ada di pedesaan dengan Jakarta mempunyai sebuah distingsi. Ritual peribadatan antara masyarakat Lamongan yang tinggal di sebuah pedesaan biasanya dalam bentuk kontrol sosial. Sistem keagamaan masyarakat Lamongan dalam menjalankan ibadahnya adalah karena tuntutan lingkungan yang mereka tempati dan kontrol sosial yang begitu kuat. Dalam menjalankan ritual keagamaan, masyarakat Lamongan yang tinggal di pedesaan biasanya dipengaruhi oleh tekanan yang berasal dari lingkungannya. Agama dalam hal ini dijalankan sebagai bentuk pelepasan dari pengucilan sosial yang terjadi di masyarakat. Mereka merasa menanggung malu ketika tidak menjalankan aktivitas keagamaan di tengah-tengah masyarakat. Generasi muda biasanya tidak mau bergaul dengan kehidupan luar rumah dan memutuskan untuk menetap di rumah mereka masing-masing. Tindakan ini dilakukan sebagai upaya untuk menghindari sanksi sosial yang ada di tengan masyarakat.

Clifford Geertz (1960), menjelaskan bahwa masyarakat muslim Jawa yang terbagi menjadi tiga kategorisasi bekerja dalam bidang masingmasing. ${ }^{59}$ Santri bekerja sebagai pedagang, priayi dalam pemerintahan serta abangan sebagai petani. Namun dalam data yang peneliti temui justru berbeda dalam artian sedikit santri yang bekerja sebagai pedagang. Kebanyakan mereka berprofesi sebagai petani yang menggarap sawah atau buruh di persawahan. Kaum abanganmayoritas bekerja sebagai pedagang soto dan membuka aneka usaha lainnya. Dalam sejarah, hubungan antara priayi dengan kalangan rakyat jelata masih terpisah secara simbolik maupun kultural. ${ }^{60}$ Kasus pada masyarakat Lamongan, menunjukan tidak semuanya masyarakat Jawa mempunyai kecenderungan yang demikian. ${ }^{61}$ Trikotomisasi ini dalam sistem keagamaaan masyarakat Jawa tentu kurang sesuai. Sebab masyarakat Jawa dalam menjalankan sistem keagamaan tidak mengalami distingsi sebagaimana yang di jelaskan oleh Clifford Geertz. Namun peneliti dalam hal ini akan membahas dalam aspek sistem mata pencaharian berdasarkan trikotomi tersebut.

${ }^{59}$ Clifford Geertz, The Religion of Java (London: The Free Press of Glencoe, 1960), 228-232.

${ }^{60}$ Zainuddin Maliki, Agama Priyayi: Makna Agama di Tangan Elit Penguasa (Yogyakarta: Pustaka Marwa, 2004), 269.

61 Adanya beragam ilustrasi diatas menunjukan betapa sulitnya membuat sebuah generalisasi tentang tata aturan pembagian warisan budaya dalam masyarakat Jawa. Lihat Bambang Pranowo, Memahami Islam Jawa (Jakarta: Pustaka Alvabet, 2009), 45 . 
Santri dan dalam perspektif Greetz (1960), mayoritas bekerja sebagai seorang pedagang atau wirausahawan. Kaum abangan identik dengan pekerjaan yang berkorelasi dengan alam sebagai petani dan nelayan. Sementara kaum priayi lebih identik dengan pekerjaan sebagai pegawai negeri sipil yang menjamin kemapanan hidup secara ekonomi di kota-kota besar. Pola keagamaan orang Lamongan di Jakarta dijalankan secara personal dan sukarela tidak ada paksaan dalam menjalankan aktivitas keagamaan. Mereka menjalankan ajaran agama dalam ruang publik secara bersama-sama. Dalam penampilan, warga Lamongan di perkotaan biasanya lebih egaliter dan tidak monoton. Fenomena yang demikian sangat berbeda dengan masyarakat Lamongan yang berada di daerah asalanya. Mereka lebih menyukai menggunakaan atribut keagamaan secara mencolok seperti menggunakan sarung atau baju yang mencerminkan ekspresi keagamaan.

Masyarakat Lamongan memaknai agama di perkotaan sebagai ajaran yang bersifat personal dan tidak di jalankan secara komunal. Mereka lebih leluasa dalam menjalankan ajaran agama di perkotaan daripada di pedesaan yang lebih bersifat terlembagakan. Diantara masyarakat yang telah suksess menjalankan usaha ada yang berpartisipasi dalam kegiatan keagamaan seperti tarekat dan berbagai majelis keagamaan yang diselenggarakan oleh masyarakat dimana mereka tinggal. Orang tua senantiasa memberikan kontrol sosial dan memberikan respon ketika anak-anak mereka meninggalkan sholat.

\section{E. Entrepreneurship dan Diferensasi Sosial Keagamaan}

Dalam orde tradisional klasifikasi berdasarkan usia, pangkat dan awu atau tali kekerabatan sangat menonjol karena hubungan sosial terjalin secara teratur. Hierarki merupakan masa bagi dimensi tradisional yang membentuk relasi antar individu dengan masyarakat. pola hubungan yang demikian tidak hanya tampak dalam bidang birokrasi atau kepangkatan sebagai orientasi dalam mengukur status sosial. Stratifikasi sosial yang dibentuk juga menyangkut jenis pekerjaan. ${ }^{62}$ Keruntuhan orde baru memberikan pengaruh pada pola oreintasi kerja masyarakat Lamongan dalam meningkatkan status sosialnya. Masyarakat Lamongan sebelum keruntuhan orde baru menempatkan golongan priayi sebagai kasta sosial khusus. Budaya priayi yang demikian kemudian membentuk pola interaksi dalam kehidupan masyarakat. Seorang pegawai pemerintahan senantiasa dihormati oleh kalangan masyarakat desa, golongan ini kemudian disusul oleh kelompok kiyai atau pemuka agama.

62 Sartono Kartodirjo, A. Sudewo dan Suhardjo Hatmosuprobo, Perkembangan Peradaban Priayi (Yogyakarta: Gadjah Mada University Press, 1993), 70.

INDO-ISLAMIKA, Volume 5 No. 2 Juli - Desember 2015/1438 | 309 
Sektor kuliner selama ini menjadi opsi bagi sebagian besar orang Lamongan yang bermigrasi ke Jakarta. Keterampilan berdagang yang melekat pada masyarakat Lamongan selama ini belum pernah diletili oleh kalangan ahli. Terutama yang berasal dari kalangan luar seperti Lance Castle yang melakukan penelitian pada industri kretek pada masyarakat Kudus atau Sarah Turner yang melakukan penelitian pada sistem kewirausahaan mikro masyarakat di Makassar Sulawesi Selatan. Berbeda dengan pendapat yang mengemukakan bahwa pencapaian status seseorang karena posisinya dalam sebuah instansi pemerintahan. Masyarakat Lamongan saat ini menilai stratifikasi sosial bukan berdasarkan tinggi rendahnya pendidikan atau posisi dalam sebuah pemerintahan. Kalangan orang tua memberikan kedudukan yang tinggi bagi masyarakat Lamongan yang telah berhasil dalam menjalankan usaha. Aspek materialisme dan sikap menghindari alienasi yang kuat menyebabkan masyarakat Lamongan mengesampingkan aspek pendidikan dan motivasi dalam jenjang karir di pemerintahan.

Sebagaimana yang penulisdeskripsikan di awal tentang konstruksi kewirausahaan masyarakat Lamongan. Peneliti menjelaskan bahwa mayoritas ikut orang di luar keluarga atau dalam lingkup orang yang berasal kampung sendiri. Pelajaran dan pengalaman secara otodidak inilah diantara faktor yang melatarbelakangi perilaku kewirausahaan masyarakat Lamongan. Keberhasilan menjalankan usaha merupakan salah satu cara untuk meningkatkan status sosial.

Seorang pedagang soto Lamongan di kawasan Kebon Jeruk Jakarta menuturkan ada kebanggaan tersendiri ketika memberikan lapangan pekerjaan. Ukuran kewibawaan bukan hanya diukur oleh nilai-nilai keagamaan maupun kapabilitas seseorang. Melainkan oleh simbol-simbol duniawi seperti harta, jabatan. ${ }^{63}$ Orang Jawa umumnya dan Lamongan khususnya memandang dan mengalami kehidupan mereka sebagai suatu keseluruhan yang bersifat sosial dan simbolis. Oleh karena itu kerangka berpikir tersebut tidak maklum dan akan kontras dengan pertentangan yang mutlak dengan dialektik, atau bahkan relativisme yang benar. ${ }^{64}$

Pada zaman penjajahan terdahulu santri melakukan aktivitas perdagangan sebagai bentuk protes terhadap kebudayaan priayi yang dianggap sebagai antek-antek Belanda. Tjokroaminoto adalah tokoh yang memelopori organisasi serikat dagang Islam yang menghimpun para pedagang yang berasal dari kalangan santri. Masyarakat Lamongan mengenal santri,abangan dan priayi dalam bentuk stratifikasi sosial, bukan dalam

${ }^{63}$ Zainuddin Maliki, Agama Priyayi: Makna Agama Di Tangan Penguasa (Yogyakarta: Pustaka Marwa, 2004), 235.

${ }^{64}$ Niels Murder, Kepribadian Jawa dan Pembangunan Nasional (Yogyakarta: Gajah Mada University Press, 1984), 52. 
bentuk aspek keagamaan sebagaimana yang dikemukakan oleh Clifford Geertz dalam trikotominya. Kalangan masyarakat abangan dianggap menempati kasta sosial terendah, sementarasantri serta priayi menempati strata sosial tertinggi.

Kalangan abangan memberontak sebagai bentuk protes terhadap masyarakat yang lebih menghargai kalangan santri. Santri bersama kiyai dianggap sebagai golongan khusus yang harus dihormati, sementara priayi dianggap sebagai pembesar. Setelah kekalahan PKI pada 1965 kalangan abangan banyak yang di marjinalkan oleh pemerintah. Termasuk kemampuan mereka dalam akses untuk menduduki posisi strategis dalam bidang pemerintahan. Kalangan marjinal ini tentu memiliih sektor swasta sebagai garapan utamanya dalam mengakumulasi ekonomi guna memenuhi kebutuhan hidupnya. Golongan ini adalah mereka yang merasa dikesampingkan oleh masyarakatnya.

Meskipun sistem kasta dalam masyarakat Jawa telah runtuh seiring dengan keruntuhan Majapahit dan masuknya Islam. Golongan tertentu dalam sebuah masyarakat merasa masih di kesampingkan dan menempati kasta sosial terendah. Mobiltas sosial adalah sebuah upaya untuk meningkatkan status sosial masyarakat Lamongan. Saluran mobilitas ini adalah menyasar dalam bidang perdagangan. Tak jarang kalangan masyarakat Lamongan yang berasal dari golongan abangan mempunyai tingkat religiusitas yang lebih tinggi daripada santri. Golongan abangan yang telah suksess dalam menjalankan usaha akan menunaikan rukun Islam yang kelima, yakni berangkat haji. Diantara golongan abangan ini bahkan ada yang menjadi donatur tetap dalam pembiayaan masjid atau musholla.

Penelitian ini sependapat dengan pernyataan Bambang Pranowo bahwa dalam sistem keagamaan masyarakat Jawa tidak terbagi secara trikotomi sebagaimana yang dikemukakan oleh Clifford Geertz yang mana golongan santri dianggap sebagai kelompok masyarakt Jawa yang taat dalam menjalankan ajaran agama dan abangan serta priayi dianggap sebagai golongan yang tidak taat menjalankan perintah agama. Kalangan masyarakat abangan dalam konteks ini menunjukan tingkat religiusitas yang lebih tinggi dariapada masyarakat santri yang mempunyai etos kerja yang rendah. Trikotomi yang demikian hanya terjadi pada status sosial, bukan dalam sistem keagamaan. Warga Lamongan berwirausaha untuk meningkatkan status sosial dalam beberapa kasus.

Orientasi kewirausahaan orang Lamongan tidak hanya dipengaruhi oleh faktor untuk meningkatkan status sosialnya dalam akumulasi kekayaan semata. Ibadah haji adalah faktor lain yang menjadi latar belakang masyarakat Lamongan dalam mendirikan wirausaha. Status tokoh agama terutama kiyai dalam masyarakat Jawa Timur masih menempati strata sosial tertinggi. Sebab stratifikasi sosial yang demikian diberikan secara khusus

INDO-ISLAMIKA, Volume 5 No. 2 Juli - Desember 2015/1438 | 311 
kepada orang-orang tertentu. Dalam masyarakat Indonesia, istilah kiyai diberikan kepada masyarakat karena perannya, bukan karean sekolah atau tinggi rendahnya pendidikan yang dicapainya.

Masyarakat yang bukan termasuk golongan kiyai atau priayi akan termotivasi untuk meningkatkan status sosialnya. Diantaranya adalah dengan akumulasi kekayaan yang dianggap sebagai sarana yang tepat dalam meningkatkan status sosialnya. Upaya yang mereka lakukan yakni dalam menyempurnakan rukun Islam yang kelima, yakni ibadah haji. Fenomena ini tidak hanya berlaku bagi santri yang mempunyai pemahaman keagamaan yang bersifat holistic. Golongan abangan yang dianggap sebagai golongan yang di kesampingkan oleh kalangan santri akan termotivasi untuk berhaji ketika menuai hasil dalam berwirausaha.

Sikap masyarakat terhadap individu yang telah menunaikan haji dalam beberapa kasus dapat menjadi motivasi berhaji. Menunaikan ibadah haji merupakan cara termudah bagi kalangan masyarakat Lamongan untuk meningkatkan status sosialnya. Gelar haji disematkan pada nama seseorang merupakan metode untuk memperoleh persamaan dengan golongan priayi atau kiyai pada masyarakat Jawa. Diantara beberapa pedagang yang peneliti wawancarai enggan untuk menyebutkan langsung namanya. Mereka senantiasa memberikan embel-embel haji di depan nama mereka. Tindakan ini dilakukan untuk memberikan penjelasan kepada penliti bahwa informan tersebut telah menunaikan ibadah haji. ${ }^{65}$

Pedagang yang telah mencapai kemapanan dalam kehidupan akan menjadi donatur dalam pembangunan tempat ibadah dan sarana keagamaan. Warga yang telah mencapai kemapanan dalam kehidupan ekonomi biasanya erat hubungannya dengan para tokoh agama. Sementara yang belum mencapai kemapanan secara ekonomi akan berusaha untuk meningkatkan status sosialnya diantara masyarakat lainnya. Upaya ini dilakukan untuk menghindari pengucilan diantara warga. Masing-masing warga berusaha untuk menonjolkan diri agar eksistensi mereka diakui oleh warga lainnya. Aktivitas yang demikian dilakukan sebagai opsi untuk meningkatkan status sosialnya.

${ }^{65}$ Wawancara dengan $\mathrm{Hj}$. Suhartini pedagang tahu campur Lamongan di Pondok Indah Jakarta selatan dan Hj. Arif di Pesanggrahan. Kedua warga Lamongan tersebut telah menuai suksess di Jakarta dan menunaikan ibadah haji. Dalam wawancara dengan kedua orang tersebut. Mereka biasanya menyematkan gelar haji di depan nama panggilan mereka. (Sumber: penelitian lapangan di Jakarta Selatan, Maret 2016). 


\section{Daftar Pustaka}

Alex, Nicholls, eds. Social Entrepreneurship: New Models of Sustainable Social Change. New York: Oxford University Press, 2006.

Atkinson, Rowland and Helms, Gesa, Eds. Securing an Urban Renaissance Crime, Community, and British Urban Policy, Bristol: University of Bristol, 2007.

Badan Pusat Statistik, Diolah dari SAKERNAS (Survei Angkatan Kerja Nasional), tahun 2013-2014.

Beugelsdijk, Sjoerd and Roger, "Entrepreneurial Culture and Economic Growth: Revisiting McClelland's Thesis," The American Journal of Economics and Sociology, Vol. 67, No. 5 (Nov., 2008),915-940.

Brown, E. Terrence. Innovation, Entrepreneurship and Culture: The Interaction between Technology, Progress and Economic Growth, USA: Edward Elgar Publishing Limited Glensanda House, 2004.

Castles, Lance. Religion Politics and Economi Behavior in Java: The Kudus Cigarette Industry. Yale University, 1967.

Cooke, Philip and Schwartz, Dafna Eds. Creative Regions Technology, culture and knowledge entrepreneurship, Canada: Routledge 2 Park Square, 2007.

Endraswara, Suwardi. Etnologi Jawa: Penelitian, Perbandingan, dan Pemaknaan Budaya, Yogyakarta: Center for Academic Publishing Service, 2015.

Evers, Hans Dieter dan Korf, Rudiger. Urbanisme di Asia Tenggara: Makan dan Kekuasaan Dalam Ruang Sosial, Jakarta: Yayasan Obor Indonesia, 2002.

Geertz, Clifford. The Religion of Java, London: The Free Press of Glencoe, 1960.

Giddens, Anthony. Kapitalisme dan Teori Sosial Modern: Suatu Analisis karya-karya Marx, Durkheim dan Max Weber, Jakarta: Universitas Indonesia, 1986.

Guang, Lie Shi. Rahasia Suksess Pebisnis Tionghoa, Yogyakarta: CV Andi Offset, 2010.

Held, David. A Globalizing World? Culture, Economics, Politics.New York: Routledge, 2004.

Hine, Damian and Kapeleris, John. Innovation and Entrepreneurship in Biotechnology, An International Perspective Concepts, Theories and Cases, Northampton Massachusetts USA: Edward Elgar Publishing Limited, 2006.

Huriyuddin. Pergeseran Kultural di Kampung Urban: Studi di Kampung Pintuair Bekasi Selatan, Jakarta: Badan Litbang Departemen Agama RI, 1997.

INDO-ISLAMIKA, Volume 5 No. 2 Juli - Desember 2015/1438 | 313 
Jonathan Rigg, Suriya Veeravongs, Lalida Veeravongs and Piyawadee Rohitarachoon, "Reconfiguring Rural Spaces and Remaking Rural lives in Central Thailand," Source: Journal of Southeast Asian Studies, Vol. 39, No. 3 (Oct, 2008), 355-381.

Jones, Eli James, A. Roberts and Chonko B, Lawrence. "Motivating Sales Entrepreneurs to Change: A Conceptual Framework of Factors Leading to Successful Change Management Initiatives in Sales Organizations," Journal of Marketing Theory and Practice, Vol. 8, No. 2, (Spring, 2000): 37-49.

Jurgen Habermas. Theories des Kommunikativen Handels, Band I: Handlungstrationaltat Und Gesselschaftliche Rationalisierung, Suhrkamp: Verlag, 1981.

Koellinger, Philipp. "Why are some entrepreneurs more innovative than others," Small Business Economics, Vol. 31, No. 1, Special Issue: International Issues in Entrepreneurship (June, 2008): 21-37.

Koentjaraningrat, Kebudayaan Mentalitas dan Pembangnan, Jakarta: PT Gramedia, 2008.

Koentjaraningrat, Sejarah Teori Antropologi II, Jakarta: Uinversitas Indonesia Press, 2010.

Koentjaraningrat. Manusia dan Kebudayaan di Indonesia, Jakarta: Djambatan, 2007.

Koentjoroningrat. Rintangan-Rintangan Mental Dalam Pembangunan Ekonomi, Jakarta: LIPI, 1980.

Köhn, Sebastian. "Entrepreneurship and the Right of the Child to a Nationality in an Era of Migration," The Annual Meeting American Society of International Law), Vol. 106 (March 2012), 67-69.

Kuntowijoyo. Budaya dan Masyarakat, Yogyakarta: Tiara Wacana Yogyakarta, 1999.

Long, Norman. An Introduction to the Sociology of Rural Development, London: Tavistock Publication Limited, 1977.

Maliki, Zainuddin. Agama Priyayi: Makna Agama di Tangan Elit Penguasa, Yogyakarta: Pustaka Marwa, 2004.

Manzi, Tony, Etc, Eds. Social Sustainability in Urban Areas: Communities, Connectivity and the Urban Fabric, London: Earthscan, 2010.

Marianne W. Jorgensen, Louise J. Phillips. Analisis Wacana Teori dan Metode, Yogyakarta: Pustaka Pelajar, 2007.

Marta Peris-Ortiz, José M. Merigó-Lindahl, Eds. Entrepreneurship, Regional Development and Culture An Institutional Perspective, (Switzerland: Springer International Publishing, 2015.

Murphy, J Patrick and Coombes, M Susan. "A Model of Social Entrepreneurial Discovery," Journal of Business Ethics, Vol. 87, No. 3 (Jul, 2009): 325-336. 
Myers, Garth. African Cities Alternative Visions of Urban Theory and Practice, London: Zed Books Ltd, 2011.

Naim, Mochtar. Merantau Pola Migrasi Suku Minangkabau. Yogyakarta: Gadjah Mada University Press, 1984.

Natsir, Nanaf Fatir. Etos Kerja Wirausahawan Muslim, Bandung: Gunung Djati Press: 1999.

Niels Murder, Kepribadian Jawa dan Pembangunan Nasional, Yogyakarta: Gajah Mada University Press, 1984.

Niels Murder, Petualangan Seorang Antropolog di Jawa, Yogyakarta: Kanisius, 2007.

Patrick Guinness. Kampung, Islam and State in Urban Java, Singapore: National University of Singapore, 2009.

Peris-Ortiz, Marta José and M. Merigó-Lindahl, Eds. Entrepreneurship, Regional Development and Culture An Institutional Perspective, Switzerland: Springer International Publishing, 2015.

Pranowo, Bambang. Memahami Islam Jawa, Jakarta: Pustaka Alvabet, 2009.

Raharjo. Pengantar Sosiologi Pedesaan dan Pertanian, Yogyakarta: Gadjah Mada University Press, 2010.

Ranjabar, Jacobus. Perubahan Sosial Dalam Teori Makro: Pendekatan Realitas Sosial, Bandung: Alfabeta, 2005.

Salim Agus. Teori Dan Paradigma Penelitian Sosial: Buku Sumber Untuk Penelitian Kualitatif. Yogyakarta: Tiara Wacana, 2006.

Salim, Agus. Teori dan Paradigma Penelitian Sosial, Yogyakarta: Tiara Wacana, 2001.

Sanderson, K Stephen. Makro Sosiologi Sebuah Pendekatan Terhadap Realitas Sosial, Jakarta: PT Raja Grafindo Persada, 2000

Sartono Kartodirjo, Sudewo, A. dan Hatmosuprobo, Suhardjo. Perkembangan Peradaban Priayi, Yogyakarta: Gadjah Mada University Press, 1993.

Scott, John. Social Theory: Central Issues in Sociology, London: SAGE Publication Ltd, 2012.

Sebani Ahmad, Beni. Pengantar Antropologi,Bandung: Pustaka Setia, 2012.

Singgih Prayitno, Ujianto. Perubahan Sosial: Dinamika Perkembangan Ilmu Pengetahuan dan Teknologi dalam Kehidupan Masyarakat, Jakarta: Publica Press, 2014.

Soekanto, Soerjono. Sosiologi Suatu Pengantar, Jakarta: PT Raja Grafindo Persada, 2002.

Soetomo, Sugiono. Urbanisasi dan Morfologi: Proses Perkembangan Peradaban dan Wadah Ruangnya Menuju Ruang yang Manusiawi, Yogyakarta: Graha Ilmu, 2013.

Solanki, S. S. "Sustainability of Rural Artisans," Economic and Political Weekly, Vol. 43, No. 19 (May 10 - 16, 2008), 24-27.

INDO-ISLAMIKA, Volume 5 No. 2 Juli - Desember 2015/1438 | 315 
Sztompka, Piotr. Sosiologi Perubahan Sosial, Jakarta: Prenada, 2004.

Titrisudarmo, Riwanto. Dinamika Sosial Pemuda di Perkotaan, Jakarta: Pustaka Sinar Harapan, 1997.

Tominc, Polona and Rebernik, Miroslav. "Growth Aspirations and Cultural Support for Entrepreneurship: A Comparison of Post-Socialist Countries," Small Business Economics, Vol. 28, No. 2/3 (Mar, 2007): 239-255.

Tracey, Paul and Phillips, Nelson. "The Distinctive Challenge of Educating Social Entrepreneurs: A Postscript and Rejoinder to the Special Issue on Entrepreneurship Education," Academy of Management Learning \& Education, Vol. 6, No. 2 (Jun, 2007): 264-271.

Turner, Sarah. Indonesia's Small Entrepreneurs Trading on the Margins, London: Routledge Curzon, 2003.

Wagener, Andreas. "Entrepreneurship and Social Security," Finanz Archiv Public Finance Analysis, Vol. 57, No. 3 (2000): 284-315.

Walzer, Norman, eds. Entrepreneurship And Local Economic Development, New York:Lexington Books, 2009.

Weber, Max. The Protestan Ethic nd The Spirit of Capitalism, Yogyakarta: Jejak, 2007.

Weber, Max. The Sociology of Religion, Jogjakarta: IRCiSoD, 2012.

Wennekers, Sander and Thurik, Roy. "Linking Entrepreneurship and Economic Growth,” Journal Small Business Economics, Vol. 13, No. 1 (Springer: 1999): 27-55. 